\title{
Prospective (Bio)leaching of Historical Copper Slags as an Alternative to Their Disposal
}

\author{
Anna Potysz *(i) and Jakub Kierczak (D) \\ Institute of Geological Sciences, University of Wroclaw, Cybulskiego 30, 50-205 Wrocław, Poland; \\ jakub.kierczak@uwr.edu.pl \\ * Correspondence: anna.potysz@uwr.edu.pl
}

Received: 2 July 2019; Accepted: 4 September 2019; Published: 9 September 2019

\begin{abstract}
The aim of this study was to evaluate the feasibility of (bio)hydrometallurgical methods for metal extraction from historical copper slags. Two types of slags (amorphous slag-AS, and crystalline slag-CS) were subjected to 24 to $48 \mathrm{~h}$ of leaching with: (i) Sulfuric acid at $0.1,0.5$, and $1 \mathrm{M}$ concentrations at $1 \%, 5 \%$, and $10 \%$ pulp densities (PDs); and (ii) normality equivalent $(2 \mathrm{~N})$ acids (sulfuric, hydrochloric, nitric, citric, and oxalic) at pulp densities ranging from $1 \%$ to $2 \%$. Bioleaching experiments were performed within 21 days with Acidithiobacillus thiooxidans accompanied by an abiotic control (sterile growth medium). The results demonstrated that the most efficient treatment for amorphous and crystalline slag was bioleaching at 1\% PD over 21 days, which led to extraction of $\mathrm{Cu}$ at rates of $98.7 \%$ and $52.1 \%$ for AS and CS, respectively. Among the chemical agents, hydrochloric acid was the most efficient and enabled $30.5 \%$ of $\mathrm{Cu}$ to be extracted from CS (1\% PD, $48 \mathrm{~h}$ ) and $98.8 \%$ of $\mathrm{Cu}$ to be extracted from AS ( $1 \% \mathrm{PD}, 24 \mathrm{~h}$ ). Slag residues after leaching were characterized by strong alteration features demonstrated by the complete dissolution of fayalite in the case of CS and the transformation of AS to amorphous silica and secondary gypsum. Based on this study, we conclude that amorphous slag is a more suitable candidate for potential metal recovery because of its generally high susceptibility to leaching and due to the generation of residue significantly depleted in metals as the end product. The inventory of economically relevant metals showed that 1 ton of historical copper slag contains metals valued at $\$ 47$ and $\$ 135$ for crystalline and amorphous slag, respectively, suggesting that secondary processing of such materials can potentially be both economically and environmentally viable.
\end{abstract}

Keywords: Cu-slag; (bio)leaching; metal recovery; Acidithiobacillus thiooxidans

\section{Introduction}

Pyrometallurgical processes involve the generation of various by-products, such as slags, sludges, ashes, and other solid residues [1]. The slags produced are substantial in volume, for example, every ton of copper produced result in the generation of a double volume equivalent of slag material [2]. In addition, slags are notable for carrying toxic elements, necessitating the suitable handling of these wastes.

Former slag disposal methods did not consider environmental safety carefully enough, which led to contamination of soils located in the vicinity of slag heaps and smelters (see [3] for a review). Some studies have also pointed out that improper slag disposal may cause serious ecological problems. For example, the study of Kasemodel et al. (2019) reveals that during transportation of slags from the smelter to the disposal site, a dirt road was heavily contaminated by slag fragments [4]. The authors conclude that high metal content in the dirt road constitutes a serious risk for the nearby population because the material is easily aerated and transported on the wind, and can be easily absorbed through inhalation [4]. Another study of Forghani et al. (2018) aimed at human risk assessment in southeastern 
Iran indicated a non-carcinogenic and carcinogenic risk to the population related with $\mathrm{Cu}$ smelting, which caused elevated concentrations of $\mathrm{Cu}$ and As in soils [5].

Despite the negative environmental effects of $\mathrm{Cu}$ slags, their binding properties result in these materials often being used for construction, with the cement industry being the most dominant consumer [6,7]. However, it is important to note that proper slag management is possible, provided that it does not entail any risk of metal discharge. If this condition is not met, then the application of slags as an engineering product is unsuitable $[8,9]$.

On the other hand, the relatively high residual metal content in slags makes these wastes appealing as secondary metal resources [10], especially when viewed in the context of the depletion of natural resource reserves. Optimal metal extraction is a process resulting in a high metal yield, but the geochemical characteristic of the remaining residue is also crucial. As a result of slag treatment, the generation of metal-free or metal-depleted residue is strongly desired [10]. Therefore, the development of suitable extraction protocols is a hotly contested subject of waste management debates [11-15].

Furthermore, the consideration of metallurgical slags as secondary metal resources has received important interest not only for environmental reasons but also for economic ones [16]. The latter involves the finite quantities of natural reserves of raw ores [17] and society's increasing demand for metal-based commodities $[18,19]$. Metal extraction from solid wastes is performed by means of chemical, biological, or combined methods [20-23]. Extraction efficiency strongly depends on slag composition and operative parameters, mainly the grain size, pulp density, temperature, and treatment time. Optimal parameters have to be selected so that energy consumption and cost-intensive operations are satisfactorily minimized. Biological methods involve the use of bacteria and/or fungi in single- or multi-species suspensions [10]. A biological process is preferred due to its environmentally friendly specification, but it usually requires a longer time to reach a comparable efficiency to that achieved by a chemical process. In addition, the optimization of bioleaching conditions is more challenging as compared to chemical leaching, mainly due to a possible metal toxicity effect on the microorganisms and the associated concerns with microbial survivors and activity [24]. These shortcomings are often difficult to overcome, which has driven the development of hybrid processes combining chemical and biotic techniques [25]. A hybrid approach can be accomplished in a way that a microbial-derived solution is generated in a reactor and then diverted to a separate slag-containing reactor in order to execute the extraction process. Chemical leaching involving the use of chemical agent(s) simulating a microbial by-product is thus a model approach. A well-crafted feasibility study allows for the evaluation of slag vulnerability in respect to metal leaching with a simultaneous preliminary optimization of the operative parameters. In this vein, sulfuric acid $\left(\mathrm{H}_{2} \mathrm{SO}_{4}\right)$ leaching is well known for its good metal extraction efficiency [20]; however, this traditional chemical reagent can also be replaced by a biologically produced one $[11,13,14]$. Likewise, organic acids produced in the presence of microbial consortia can contribute to the extraction process as well $[15,26,27]$. Therefore, the use of these acids is reasonable for a simplified model of the biotic process and for shaping its optimal conditions.

Literature data presents a number of (bio)leaching approaches undertaken for copper slags (see $[10,20]$ for a review). It has been demonstrated that chemical leaching can be carried out with various extractants, such as: Ferric chloride [28], ferric sulfate [22,29,30], ammonium sulfate [31], ammonium chloride [32], chlorine solution [30,33], hydrochloric acid, ammonium hydroxide [34], and sulfuric acid $[21,23,28-31,34-39]$. Some studies reveal that an additional treatment step, such as slag roasting following leaching [28,29,31,37], aging of slag [23], oxidant addition [21,34,35,38], or high-temperature leaching $[21-23,28,30,32,34,36]$, may be required in order to improve the leaching yield. However, it has to be noted that each additional step consumes energy, while an economically viable process requires the number of cost-intensive operations to be minimized. Furthermore, numerous approaches have also addressed the bioleaching of copper slags. It has been shown that a high yield of copper can be achieved under optimized conditions (for an extended review, see [10]). However, based on review data, it has been established that uniform laboratory bioleaching conditions that are efficient for any type of copper slag have not yet been defined [10]. Nevertheless, among 
the (bio)leaching parameters strongly affecting the process efficiency, particle size and pulp density were found to be very important. Furthermore, a key slag feature to the efficiency of the (bio)leaching processes is the sample crystallinity. It is known that crystalline and amorphous slags reveal different chemical and phase compositions [20]. Thus, the susceptibility of these slags to the leaching process also varies. Some recent comparative studies addressing the behavior of amorphous and crystalline slags demonstrated that element release is strongly dependent on the phase component that the metal is associated with [14,40]. For this reason, the search for optimal (bio)leaching conditions should definitely take into account the crystallinity aspect because it will deliver important information on how the behavior of different materials varies under specific conditions. In regard to the aforementioned facts, there seems to be interest in undertaking laboratory work dedicated to the search for optimal (bio)leaching conditions, with a special focus given to slag crystallinity.

The aim of this study was to investigate the feasibility of biological and chemical treatments of metal-laden historical metallurgical slags disposed of in Poland. The main novelty of this study is that it compared chemical and biological treatments of two types of copper historical slags (crystalline and amorphous). The specific research objectives included the search for the optimal operating parameters among acid types (inorganic vs. organic normality equivalent acids), pulp density for metal extraction, as well as the optimal conditions for biotic treatment, with a particular focus placed on pulp density. In addition, the economic potential of each approach was estimated based on the amounts of recovered metals.

\section{Materials and Methods}

\subsection{Materials}

The metallurgical slags chosen for this study were: (i) Crystalline fayalite-bearing slag (CS) and (ii) amorphous slag (AS), both resulting from former copper production. An overview of the chemical and mineralogical composition of these wastes is presented in Table 1 and Figure 1, whereas a detailed characterization is given elsewhere [41-43]. Crystalline slag is mainly (nearly 83\%) composed of $\mathrm{SiO}_{2}$ and $\mathrm{FeO}$, whereas amorphous slag's main components are $\mathrm{SiO}_{2}, \mathrm{FeO}$, and $\mathrm{CaO}$ (nearly 78\%). Amorphous slag contains a higher content of $\mathrm{Cu}$ than $\mathrm{CS}$, whereas the latter is more abundant in $\mathrm{Zn}$ (Table 1). Fayalite and glass are volumetrically major components of CS, whereas amorphous slag is mainly composed of glass. Both slag types contain various metal-bearing phases (mainly sulfides in the case of $\mathrm{CS}$ or metallic $\mathrm{Cu}$ in the case of AS) occurring in minor volumetric proportions (Table 1). 
Table 1. Chemical composition of studied slags (CS: crystalline slag, AS: amorphous slag).

\begin{tabular}{|c|c|c|}
\hline Sample ID & CS & AS \\
\hline \multicolumn{3}{|c|}{ Major and minor elements (wt. \%) } \\
\hline $\mathrm{SiO}_{2}$ & 38.26 & 48.33 \\
\hline $\mathrm{TiO}_{2}$ & 0.58 & 0.57 \\
\hline $\mathrm{Al}_{2} \mathrm{O}_{3}$ & 9.29 & 11.81 \\
\hline $\mathrm{FeO}$ & 44.33 & 12.11 \\
\hline $\mathrm{MnO}$ & 0.25 & 0.49 \\
\hline $\mathrm{MgO}$ & 2.97 & 2.10 \\
\hline $\mathrm{CaO}$ & 0.68 & 17.47 \\
\hline $\mathrm{Na}_{2} \mathrm{O}$ & 0.19 & 0.21 \\
\hline $\mathrm{K}_{2} \mathrm{O}$ & 1.27 & 4.59 \\
\hline \multicolumn{3}{|c|}{ Minor and trace elements $\left(\mathrm{mg} \mathrm{kg}^{-1}\right)$} \\
\hline $\mathrm{Cu}$ & 3761 & 19,724 \\
\hline $\mathrm{Pb}$ & 55 & 53 \\
\hline $\mathrm{Zn}$ & 3628 & 587 \\
\hline \multicolumn{3}{|c|}{ Phase composition } \\
\hline & $\begin{array}{c}\text { Fayalite }\left(\mathrm{Fe}^{2+}{ }_{2} \mathrm{SiO}_{4}\right)^{++} \\
\text {Glass } \\
\text { Hercynite }\left(\mathrm{FeAl}_{2} \mathrm{O}_{4}\right)^{+} \\
\text {Bornite }\left(\mathrm{Cu}_{5} \mathrm{FeS}_{4}\right)^{+} \\
\text {Pyrrhotite }\left(\mathrm{Fe}_{(\mathrm{x}-1)} \mathrm{S}\right)^{+} \\
\text {Chalcopyrite }\left(\mathrm{CuFeS}_{2}\right)^{(+)}\end{array}$ & $\begin{array}{c}\text { Glass }{ }^{++} \\
\text {Chalcocite }\left(\mathrm{Cu}_{2} \mathrm{~S}\right)^{+} \\
\text {Quartz }\left(\mathrm{SiO}_{2}\right)^{+} \\
\text {Cristobalite }\left(\mathrm{SiO}_{2}\right)^{+} \\
\text {Metallic } \mathrm{Cu}^{+}\end{array}$ \\
\hline
\end{tabular}
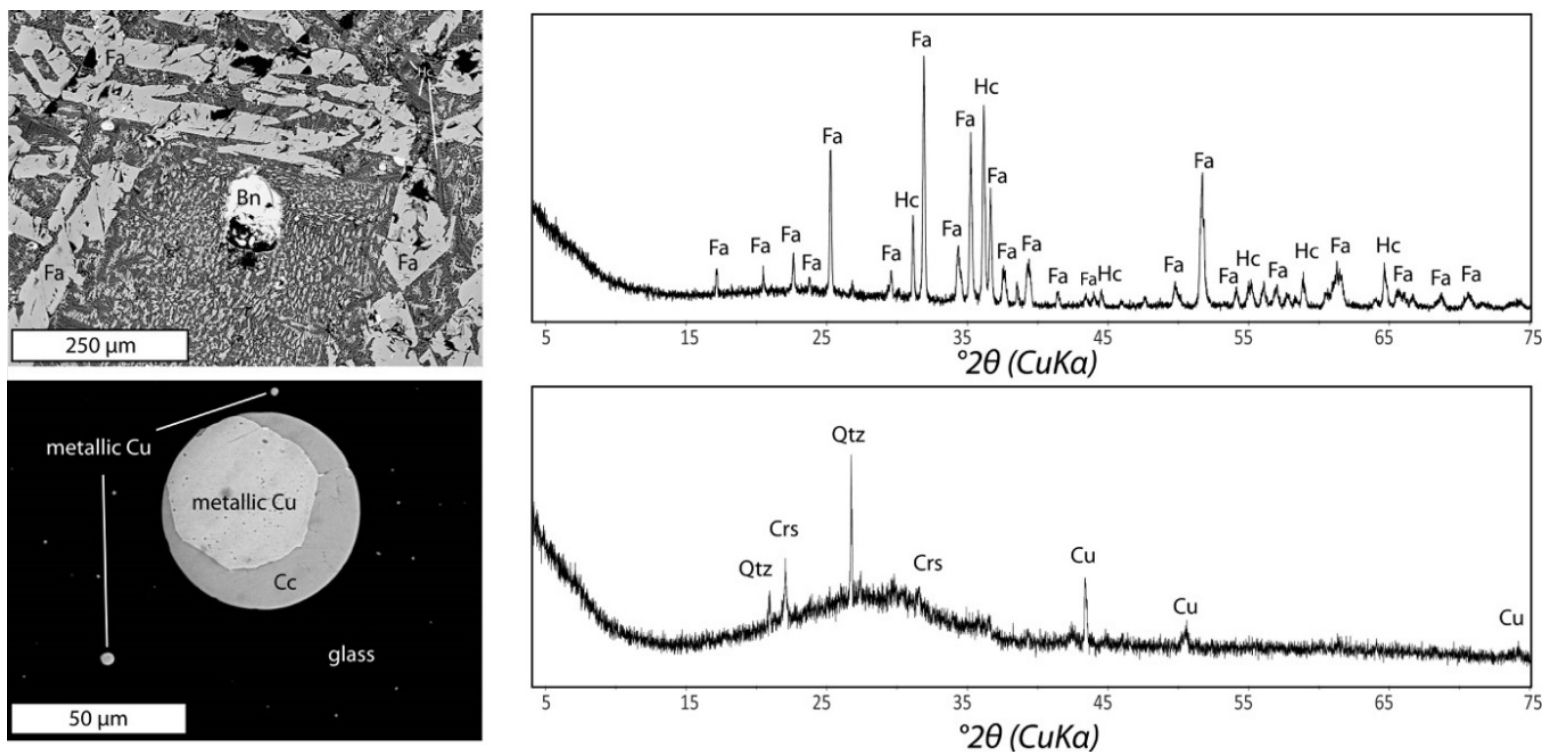

Figure 1. Scanning electron microscope images and XRD patterns of fresh samples of crystalline (upper pictures) and amorphous slag (bottom pictures). Abbreviations: Fa: fayalite, Hc: hercynite, Qtz: quartz, Crs: cristobalite, $\mathrm{Cu}$ : metallic copper, Bn: bornite, $\mathrm{Cc}$ : chalcocite.

\subsection{Experimental Procedures}

Metallurgical slags were subjected to extraction with an inorganic solution in order to demonstrate the samples' general behavior and the effect of the processing parameters. The first series of experiments was carried out with sulfuric acid $\left(\mathrm{H}_{2} \mathrm{SO}_{4}\right)$ and the evaluated parameters were as follows: Acid concentration $\left(0.1 \mathrm{M} \mathrm{L}^{-1}, 0.5 \mathrm{M} \mathrm{L}^{-1}\right.$, and $\left.1 \mathrm{M} \mathrm{L}^{-1}\right)$, pulp density $(1 \%, 5 \%$, and $10 \%)$, and extraction 
time (24 and $48 \mathrm{~h})$. Sulfuric acid $\left(\mathrm{H}_{2} \mathrm{SO}_{4}\right)$ was chosen, as this extracting agent is known for its good performance in the slag leaching process [20]. The slag section used for the screening experiments was 0.25 to $0.5 \mathrm{~mm}$ in order to increase the slag surface area and therefore improve the accessibility of the leaching solution to the metal bearing phases contained within. The agitation speed was set at $150 \mathrm{rpm}$ and kept constant for all the experiments.

Once the most optimal parameters were selected based on the results from the first experimental series, other extracting configurations were tested. The extracting normality equivalent $(2 \mathrm{~N})$ solutions were $1 \mathrm{M} \mathrm{L}^{-1}$ sulfuric acid $\left(\mathrm{H}_{2} \mathrm{SO}_{4}\right), 2 \mathrm{M} \mathrm{L}^{-1}$ hydrochloric acid $(\mathrm{HCl}), 2 \mathrm{M} \mathrm{L}^{-1}$ nitric acid $\left(\mathrm{HNO}_{3}\right)$, $0.66 \mathrm{M} \mathrm{L}^{-1}$ citric acid $\left(\mathrm{C}_{6} \mathrm{H}_{8} \mathrm{O}_{7}\right)$, and $1 \mathrm{M} \mathrm{L}^{-1}$ oxalic acid $\left(\mathrm{H}_{2} \mathrm{C}_{2} \mathrm{O}_{4}\right)$; all the reagents were analytical grade. The pulp densities used consisted of $1 \%, 2 \%$, and $3 \%$ concentrations. The leaching time was extended from 24 to $48 \mathrm{~h}$. All the extractions were carried out at least in duplicate. The leachates were filtered using 0.45- $\mu \mathrm{m}$ PTFE (polytetrafluoroethylene) syringe filters, acidified using 2 vol. \% Suprapur $\mathrm{HNO}_{3}$ (Merck) and stored at $4{ }^{\circ} \mathrm{C}$ until analysis.

Bioleaching experiments (GMB) were performed with Acidithiobacillus thiooxidans (strain number DSM 9463; purchased from Deutsche Sammlung von Mikroorganismen und Zellkulturen) and were accompanied by control experiments done with a sterile growth medium (GM). The growth medium used was composed of $2 \mathrm{~g}$ ammonium sulfate $\left(\left(\mathrm{NH}_{4}\right)_{2} \mathrm{SO}_{4}\right), 0.25 \mathrm{~g}$ magnesium sulfate $\left(\mathrm{MgSO}_{4} \cdot 7 \mathrm{H}_{2} \mathrm{O}\right)$, $0.1 \mathrm{~g}$ dipotassium hydrogen phosphate $\left(\mathrm{K}_{2} \mathrm{HPO}_{4}\right), 0.1 \mathrm{~g}$ potassium chloride $(\mathrm{KCl})$, and $1 \%(\mathrm{wt} . / \mathrm{v})$ elemental sulfur (S) per $1 \mathrm{~L}$ of ultrapure water. The $\mathrm{pH}$ of the growth medium was adjusted to 3.5 . No additional $\mathrm{pH}$ adjustments were done while the experiment was run, because leaving the $\mathrm{pH}$ in a free drift enables the tracking of microbial activity in the biotic incubation. When Acidithiobacillus thiooxidans acts, a gradual $\mathrm{pH}$ depletion is expected as the result of sulfur oxidation. The bacterial culture used for the bioleaching experiment was pre-grown in a growth medium for a period of two weeks. Then, $2 \%(\mathrm{v} / \mathrm{v})$ of inoculum was introduced to each biotic incubation, whereas no bacteria were added to the abiotic control.

The duration of the experiments was 21 days, because a previous study on copper slags revealed this time frame to be optimal for metal extraction yields. The section size of 0.25 to $0.5 \mathrm{~mm}$ was selected because a previous study [14] revealed that a smaller $(<2 \mathrm{~mm})$ slag particle size allows a better extraction efficiency to be reached. Thus, an intermediate fraction was used in this study with a slightly higher pulp density range (i.e., $1 \%, 2 \%$, and $5 \%$ ). At the end of the extraction procedure, slag residue grains were gently rinsed with ultrapure water and dried at room temperature.

As the metals leached from slags may pose a toxicity stress to bacteria, the microbial survivor rate was evaluated via an activity test $[14,44]$. In total, $1 \mathrm{~mL}$ of leachate from each biotic (GMB) and abiotic (GM) flask was transferred to tubes containing a sterile growth medium supplemented with $1 \%$ elemental sulfur. The test was accompanied by a procedural blank with growth medium and sulfur (with no leachate addition). After leachate addition, all tubes were closed with cotton plugs, kept for 10 days, and observed with respect to sulfur oxidation. A lack of microbial activity occurred when sulfur remained floating on the medium surface, whereas positive bacterial activity occurred when sulfur settled down in the tube.

\subsection{Analytical Measurements}

\subsubsection{Solution Chemistry}

The leaching solution was analyzed for elemental composition using inductively coupled plasma atomic mass spectrometry (Agilent Technologies-Agilent 7700x, Agilent Technologies, Inc., Santa Clara, CA, USA), with Sc used as an internal standard. The standard deviation of the measurements was below 5\%. Each 10-sample standard solution was analyzed in order to check the accuracy of the measurement. Samples were analyzed using different dilutions in order to ensure quality and check the repeatability of the obtained data. The $\mathrm{pH}$ of the leachates was measured using an Elmetron CP-411 
pH-meter (Elmetron, Zabrze, Poland) equipped with an ERH-11S electrode (Elmetron, Zabrze, Poland). The $\mathrm{pH}$ values for each leachate are presented in Table 2.

Table 2. The final $\mathrm{pH}$ values in the leachates from executed treatments.

\begin{tabular}{|c|c|c|c|}
\hline \multirow[b]{2}{*}{ Solution Used as Extracting Agent } & \multirow[b]{2}{*}{ Operating Parameters } & \multicolumn{2}{|c|}{ Final pH Values in the Leachates } \\
\hline & & Crystalline Slag & Amorphous Slag \\
\hline \multicolumn{4}{|l|}{ Sulfuric Acid (0.1-1 M) } \\
\hline \multirow{3}{*}{ Sulfuric acid } & 0.1 M, PD: 1\%, T: 48 h & 1.22 & 1.45 \\
\hline & $0.1 \mathrm{M}, \mathrm{PD}: 5 \%, \mathrm{~T}: 48 \mathrm{~h}$ & 1.31 & 1.60 \\
\hline & $0.1 \mathrm{M}, \mathrm{PD}: 10 \%, \mathrm{~T}: 48 \mathrm{~h}$ & 1.36 & 1.68 \\
\hline \multirow{3}{*}{ Sulfuric acid } & $0.5 \mathrm{M}, \mathrm{PD}: 1 \%, \mathrm{~T}: 48 \mathrm{~h}$ & 0.51 & 0.56 \\
\hline & 0.5 M, PD: $5 \%, \mathrm{~T}: 48 \mathrm{~h}$ & 0.52 & 0.62 \\
\hline & 0.5 M, PD: $10 \%$, T: $48 \mathrm{~h}$ & 0.60 & 0.70 \\
\hline \multirow{3}{*}{ Sulfuric acid } & $1 \mathrm{M}, \mathrm{PD}: 1 \%, \mathrm{~T}: 48 \mathrm{~h}$ & 0.38 & 0.31 \\
\hline & $1 \mathrm{M}, \mathrm{PD}: 5 \%, \mathrm{~T}: 48 \mathrm{~h}$ & 0.40 & 0.35 \\
\hline & $1 \mathrm{M}, \mathrm{PD}: 10 \%, \mathrm{~T}: 48 \mathrm{~h}$ & 0.39 & 0.36 \\
\hline \multicolumn{4}{|l|}{ Normality Equivalent Acids (2N) } \\
\hline \multirow{2}{*}{ Hydrochloric acid } & PD: $1 \%, \mathrm{~T}: 48 \mathrm{~h}$ & 0.04 & 0.05 \\
\hline & PD: $2 \%, \mathrm{~T}: 48 \mathrm{~h}$ & 0.08 & 0.17 \\
\hline \multirow{2}{*}{ Sulfuric acid } & PD: $1 \%, \mathrm{~T}: 48 \mathrm{~h}$ & 0.38 & 0.31 \\
\hline & PD: $2 \%, \mathrm{~T}: 48 \mathrm{~h}$ & 0.41 & 0.40 \\
\hline \multirow{2}{*}{ Nitric acid } & PD: $1 \%, \mathrm{~T}: 48 \mathrm{~h}$ & 0.12 & 0.05 \\
\hline & PD: $2 \%, \mathrm{~T}: 48 \mathrm{~h}$ & 0.11 & 0.11 \\
\hline \multirow{2}{*}{ Citric acid } & PD: $1 \%, \mathrm{~T}: 48 \mathrm{~h}$ & 1.99 & 2.03 \\
\hline & PD: $2 \%, \mathrm{~T}: 48 \mathrm{~h}$ & 2.08 & 2.29 \\
\hline \multirow{2}{*}{ Oxalic acid } & PD: $1 \%, \mathrm{~T}: 48 \mathrm{~h}$ & 0.77 & 1.48 \\
\hline & PD: $2 \%, \mathrm{~T}: 48 \mathrm{~h}$ & 0.80 & 2.19 \\
\hline \multicolumn{4}{|l|}{ (Bio)leaching } \\
\hline \multirow{3}{*}{ Growth medium (sterile) } & PD: $1 \%, \mathrm{~T}: 21$ days & 3.98 & 4.83 \\
\hline & PD: $2 \%, \mathrm{~T}: 21$ days & 3.88 & 4.65 \\
\hline & PD: 3\%, T: 21 days & 3.85 & 4.60 \\
\hline \multirow{3}{*}{ Growth medium + bacteria } & PD: $1 \%, \mathrm{~T}: 21$ days & 0.90 & 0.62 \\
\hline & PD: $2 \%, \mathrm{~T}: 21$ days & 1.15 & 0.71 \\
\hline & PD: $3 \%, \mathrm{~T}: 21$ days & 1.43 & 0.98 \\
\hline
\end{tabular}

Abbreviations: PD—pulp density, T-treatment time.

\subsubsection{Mineralogical Analyses}

Scanning electron microscope observations were performed before and after the leaching experiments. Thin sections and/or slag grains were carbon-coated and observed using a scanning electron microscope (SEM-EDS JEOL JSM-IT100, JEOL, Tokyo, Japan) operating at high vacuum and in the $15-20 \mathrm{kV}$ working mode.

X-ray powder diffraction analyses of pulverized slag samples (fraction $0.25-0.5 \mathrm{~mm}$ ) were made using a Bruker D8 Advance diffractometer (Bruker, Billerica, MA, USA) with CuK $\alpha(1.54060 \AA)$ radiation operating at $40 \mathrm{kV}$ and $40 \mathrm{~mA}$. The analyses were recorded in the range of 2-theta angles from $4^{\circ}$ to $75^{\circ}$ at a rate of $6^{\circ} 2 \theta / \mathrm{min}$.

\section{Results and Discussion}

\subsection{Effect of Sulfuric Acid Concentration}

The analysis of how acid concentration and pulp density influence the extraction yield was performed using $\mathrm{H}_{2} \mathrm{SO}_{4}$. This chemical agent was selected because it had previously been proven to perform well in the extraction process on various copper slags $[20,21,30,36]$. The literature reports a positive correlation between the concentration of acid used and extraction yield achieved [23,38]. 
However, an economically viable extraction process requires the amount of chemicals consumed to be minimized. Therefore, the acid concentration used in the present study ranged from 0.1 to $1 \mathrm{M}$ (Figure 2). The $\mathrm{pH}$ values obtained in the final leachates are presented in Table 2.

\subsubsection{Crystalline Slag}

In the case of crystalline slag (CS), the results demonstrated that maximal extraction for most elements studied (with the exception of $\mathrm{Cu}$ ) was generally achieved when $1 \mathrm{M} \mathrm{H}_{2} \mathrm{SO}_{4}$ and $1 \%$ slag pulp density conditions were used (Figure 2). Such operating conditions enabled the extraction of as much as $59.9 \%$ of $\mathrm{Zn}\left(2173 \mathrm{mg} \mathrm{kg}^{-1}\right)$ and $52.5 \%$ of Fe $\left(181 \mathrm{~g} \mathrm{~kg}^{-1}\right)$, whereas the extraction efficiency for Cu was surprisingly low at $1.4 \%\left(53.1 \mathrm{mg} \mathrm{kg}^{-1}\right)$. A similar observation occurred with the study of Stuurman et al. (2014), who demonstrated decreasing $\mathrm{Cu}$ extraction from $\mathrm{Cu} / \mathrm{Co}$ ores once the $\mathrm{H}_{2} \mathrm{SO}_{4}$ concentration used surpassed $0.8 \mathrm{M}$ [45]. Thus, it remains to be elucidated what secondary precipitation process is responsible for such low $\mathrm{Cu}$ leaching. It has to be emphasized that $\mathrm{Cu}$ leachability from $\mathrm{CS}$ is generally high, as proven by several previous studies (e.g., [40]), therefore it is clear that an additional factor must have played a role in the leaching system studied here (discussed in detail in Section 3.3).

Furthermore, the results demonstrated that an increase of acid molarity from 0.1 to $1 \mathrm{M}$ notably enhanced the extraction of $\mathrm{Zn}$ and Si. This difference was especially pronounced when $1 \%$ of CS pulp was used in the extraction process. In this case, a higher acid molarity $(1 \mathrm{M})$ enabled 6.1 times more $\mathrm{Zn}$ (nearly $60 \%$ ) to be extracted as compared to the extraction reached when using $0.1 \mathrm{M}$ acid (only $9.8 \%$ ). Likewise, the extraction of $\mathrm{Si}$ was enhanced by a factor of 3.3 once the acid molarity increased from 0.1 to $1 \mathrm{M}$. Both $\mathrm{Si}$ and $\mathrm{Zn}$ are elements incorporated in glass and fayalite, therefore no conclusion can be made concerning which phase is responsible for $\mathrm{Zn}$ input to the leachate. The effect of normality equivalent acids is discussed in Section 3.2 (Figure 3).

Undoubtedly, an improvement of $\mathrm{Cu}$ leaching from CS could be achieved when a higher temperature is applied, because thermal activation improves phase dissolution (in this case $\mathrm{Cu}$-sulfides) [46,47]. According to literature reports, high $\mathrm{Cu}$-recovery rates from slags could be achieved when leaching was performed at higher temperatures ([20] and references therein). For example, Sukla et al. (1986) extracted $95 \%$ of $\mathrm{Cu}$ within 1 hour of leaching at $150^{\circ} \mathrm{C}$ [31]. Likewise, Beşe (2007) accomplished an $80 \% \mathrm{Cu}$ removal from slags at $65^{\circ} \mathrm{C}$ [48]. On the other hand, it has to be remembered that a higher slag dissolution is associated with a higher content of $\mathrm{Si}$ in the solution and, therefore, a higher risk of silica colloid formation may be an important process shortcoming [49] (discussed in detail in Section 3.3).

\subsubsection{Amorphous Slag}

Amorphous slag (AS) subjected to extraction with sulfuric acid appeared to have a higher susceptibility to extraction than CS, especially when $\mathrm{Cu}$ is considered. For example, as much as $63.3 \%$ of $\mathrm{Cu}\left(12,500 \mathrm{mg} \mathrm{kg}^{-1}\right)$ was extracted after $48 \mathrm{~h}$ with $1 \mathrm{M} \mathrm{H}_{2} \mathrm{SO}_{4}$ at $1 \% \mathrm{PD}$ (Figure 4). However, an important observation concerning the behavior of AS in the leaching system is that the metal amount extracted in $1 \mathrm{M}$ acid was nearly the same as the amount extracted with $0.5 \mathrm{M}$ acid. For example, $\mathrm{Cu}$ extraction with $0.5 \mathrm{M} \mathrm{H}_{2} \mathrm{SO}_{4}$ varied in the range of $15.4 \%$ to $65.6 \%$ (depending on the pulp density used), whereas the amounts achieved using $1 \mathrm{M}$ acid ranged between $24.7 \%$ to $63.3 \%$. This observation is valid for all the metals studied (Figure 4). In contrast, the difference between $0.1 \mathrm{M}$ and $0.5 \mathrm{M}$ acid used for AS extraction was more pronounced and it was especially notable when AS was treated at the $1 \%$ pulp density. For example, an increase of acid concentration from 0.1 to $0.5 \mathrm{M}$ enabled extraction yields to be improved by a factor of at least 1.8 (for $\mathrm{Cu}$ and $\mathrm{Zn}$ ), and up to 2.7 (for $\mathrm{Pb}$ ). Amorphous slag was found to release the highest quantities of metals when leached with $\mathrm{HCl}$, as up to $98.8 \%$ of $\mathrm{Cu}$ $\left(18,211 \mathrm{mg} \mathrm{kg}^{-1}\right)$ and $81.3 \%$ of $\mathrm{Zn}\left(478 \mathrm{mg} \mathrm{kg}^{-1}\right)$ could be extracted (Figure 5). 


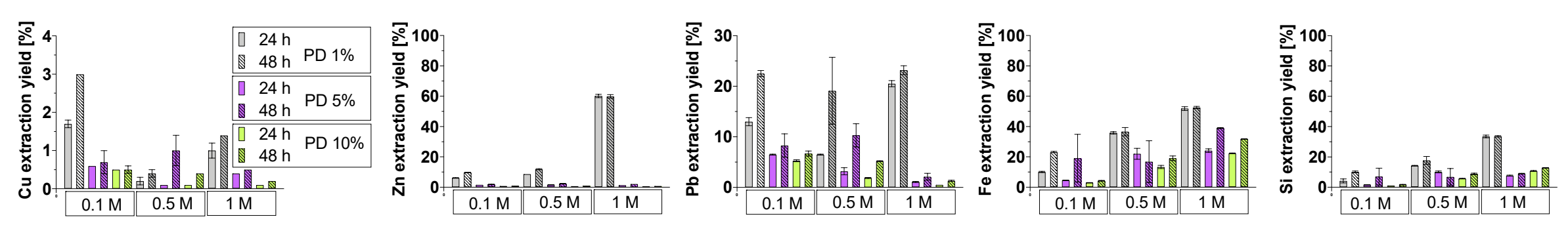

Figure 2. Chemical extraction of metals from crystalline slag treated with sulfuric acid at different concentrations $(0.1-1 \mathrm{M})$ and various pulp densities (1-10\%).
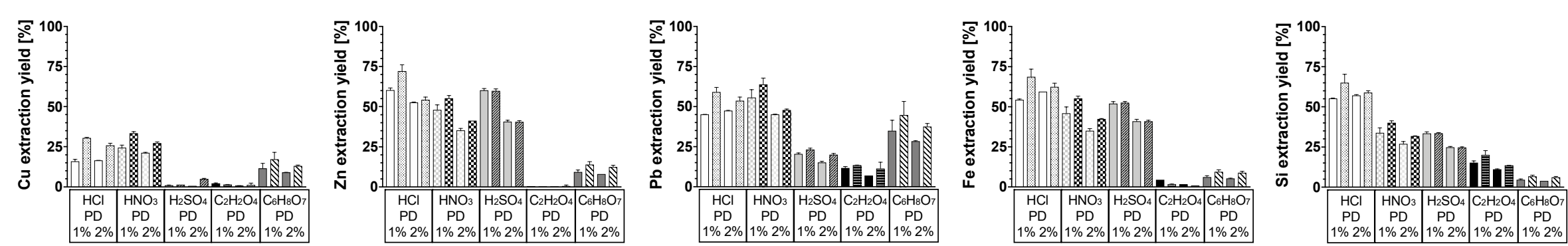

Figure 3. Chemical extraction of metals from crystalline slag treated with normality equivalent $(2 \mathrm{~N})$ acids at various pulp densities $(1-2 \%)$.
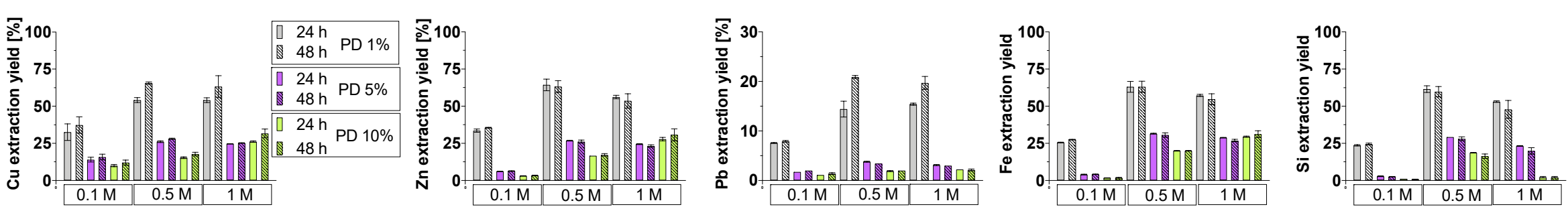

Figure 4. Chemical extraction of metals from amorphous slag treated with sulfuric acid at different concentrations ( $0.1-1 \mathrm{M})$ and various pulp densities (1-10\%). 

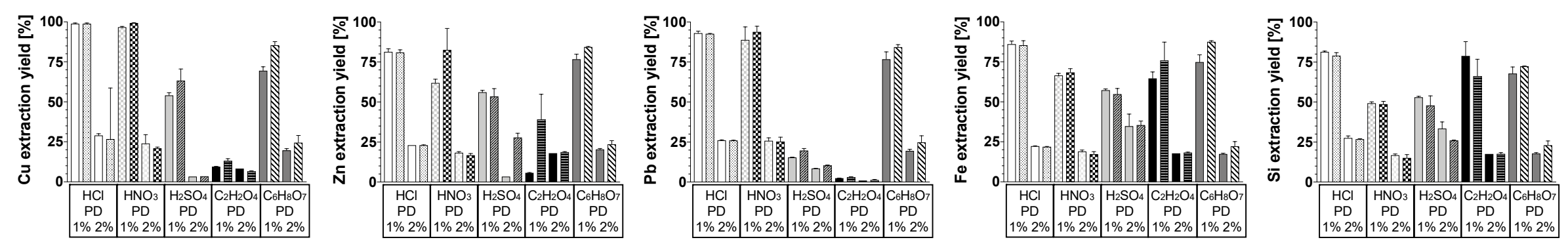

Figure 5. Chemical extraction of metals from amorphous slag treated with normality equivalent ( $2 \mathrm{~N})$ acids at various pulp densities (1-2\%). 
A screening study of leaching efficiency with $\mathrm{H}_{2} \mathrm{SO}_{4}$ showed that $\mathrm{CS}$ is treated more efficiently with $1 \mathrm{M}$ acid. Thus, $1 \mathrm{M}$ acid was selected for equ-normal acid extraction in order to enable a comparison of the leaching susceptibility of crystalline and amorphous slags.

Among the organic extractants studied, citric acid was found to have better performance as compared to oxalic acid and additionally, AS susceptibility to leach metals in the presence of citric acid was higher than that observed for CS. For example, even $69.5 \%$ of $\mathrm{Cu}\left(13,708 \mathrm{mg} \mathrm{kg}^{-1}\right)$ and $84.3 \%$ of $\mathrm{Zn}$ $\left(495 \mathrm{mg} \mathrm{kg}^{-1}\right)$ was extracted from AS with citric acid with $1 \%$ PD. This indicates that the susceptibility of AS to organic solution is higher than the susceptibility recorded for crystalline slag. This observation is in accordance with previous studies concerning the leaching of CS and AS in organic solutions (a mixture of various organic acids) [43,50]. A prime advantage of the use of AS in chemical treatment is the fact that it contains a lower amount of Fe. This point is crucial when selective recovery (e.g., $\mathrm{Cu}$ ) is targeted, because Fe purification from a pregnant leachate is such a challenging aspect [51-53]. Iron extraction in organic leaching media (citric and oxalic acid) was relatively high (up to $87.5 \%$ ) in the case of AS leaching at $1 \%$ PD, whereas the amount of Fe decreased to $22 \%$ when $2 \%$ PD was used. Such a change may not only be related to a higher pulp density but in fact be due to $\mathrm{Fe}$ (III) citrate formation, which is relatively stable and dissolves slowly [54].

\subsection{Effect of Pulp Density}

Pulp density (PD) is an important economic driver of the extraction process because, for instance, the use of a $2 \%$ pulp density instead of $1 \%$ enables the consumption of chemical agents to be reduced by a factor of two [55]. A wide range of pulp densities (1\%, 5\%, and 10\%) used for $\mathrm{H}_{2} \mathrm{SO}_{4}$ extraction revealed the latter as being the least favorable for extraction. For example, over $60 \%$ of $\mathrm{Zn}\left(2184 \mathrm{mg} \mathrm{kg}^{-1}\right)$ was extracted from CS using $1 \% \mathrm{PD}$ and $1 \mathrm{M} \mathrm{H}_{2} \mathrm{SO}_{4}$, whereas an increase of PD to $10 \%$ allowed for the extraction of $\mathrm{Zn}$ in an amount not exceeding $1 \%\left(28.5 \mathrm{mg} \mathrm{kg}^{-1}\right)$. Thus, using a 10 -fold higher pulp density affected the extraction such that the yield was over 75 times lower. One can assume that a higher $\mathrm{PD}$ is associated with a higher neutralizing capacity of the slag. As shown in Table 2, a pH recorded in the reactors of $1 \%$ to $10 \%$ PD showed some variations, however, the main factor that determined the lower slag extraction rate at $10 \% \mathrm{PD}$ is the limited phase exposure to the leaching solution.

A similar observation applies to AS that released even $63.3 \%$ of $\mathrm{Cu}\left(12,500 \mathrm{mg} \mathrm{kg}^{-1}\right)$ during extraction at conditions $1 \% \mathrm{PD}$ and $1 \mathrm{M} \mathrm{H}_{2} \mathrm{SO}_{4}$, whereas only $31.7 \%$ of $\mathrm{Cu}\left(6248 \mathrm{mg} \mathrm{kg}^{-1}\right)$ was extracted when $\mathrm{PD}$ increased from $1 \%$ to $10 \%$, while $\mathrm{pH}$ variations were also rather marginal (Table 2). Thus, the extraction efficiency decreased by a factor of 2, which indicated a much lower impact of AS pulp density than in the case of CS. This supports the conclusion that AS reveals a higher susceptibility to leaching with $\mathrm{H}_{2} \mathrm{SO}_{4}$ than $\mathrm{CS}$ does. A greater leachability of amorphous materials than crystalline ones has already been mentioned in the literature [56].

A study on pulp densities (1\% and 2\%) using various chemical agents (Figures 3 and 5 ) revealed that even a narrow range of $\mathrm{PD}$ of $1 \%$ to $2 \%$ slightly affects the process's efficiency. For example, $\mathrm{Cu}$ extraction from $\mathrm{CS}$ using $\mathrm{HNO}_{3}$ solution at $1 \%$ PD was $33.5 \%\left(1259 \mathrm{mg} \mathrm{kg}^{-1}\right)$, whereas extraction achieved at $2 \%$ PD was $27.3 \%\left(1025 \mathrm{mg} \mathrm{kg}^{-1}\right)$. Such results have also been shown in the case of AS; however, the difference between PD $1 \%$ and $2 \%$ was more pronounced there than in case of CS. For example, $\mathrm{Cu}$ extraction in $\mathrm{AS}$ with $\mathrm{HNO}_{3}$ reached $93.8 \%\left(15,634 \mathrm{mg} \mathrm{kg}^{-1}\right)$, while the use of $2 \%$ PD enabled extraction of only $25.3 \%\left(4123 \mathrm{mg} \mathrm{kg}^{-1}\right)$. This highlights the importance of a deep study of simple leaching parameters since even a narrow change of operating conditions may significantly affect the leaching efficiency. In the case of AS, the use of $1 \%$ PD in chemical treatment (Figures 4 and 5) appears to be more reasonable, because it increases the yield by factor of 3.7, while it does not show relevance in the case of CS. Decreased metal extraction efficiencies along with increasing pulp density have already been observed [22]. Thus, the amount of extractant per slag volume is more important for AS despite its generally higher susceptibility to leaching as compared to CS.

Crystalline slag subjected to 24 - to 48 -h extraction procedures using normality equivalent acids resulted in relatively high extraction yields (Figure 3). In particular, Fe and Zn were easily leachable 
elements since up to $68.6 \%$ of $\mathrm{Fe}\left(236 \mathrm{~g} \mathrm{~kg}^{-1}\right)$ and $72.1 \%$ of $\mathrm{Zn}\left(2617 \mathrm{mg} \mathrm{kg}^{-1}\right)$ were extracted when $2 \mathrm{M} \mathrm{HCl}$ was used as a leaching agent in conjunction with $1 \%$ pulp density. A high leachability of $\mathrm{Fe}$ and $\mathrm{Zn}$ again confirms the general fayalite susceptibility to dissolution. Although, Fe and $\mathrm{Zn}$ are also incorporated in glass, fayalite is a primary Fe and $\mathrm{Zn}$ carrier in this slag [41]. In addition, extraction rates of Si were also exceptionally high, reaching up to $97.8 \%$. Therefore, it can be stated that not only was fayalite a highly soluble phase under such conditions but glass also was, and silica gel formation likely did not occur as it did in the case of $\mathrm{H}_{2} \mathrm{SO}_{4}$ leaching. That resulted in an improved $\mathrm{Cu}$ extraction yield (compared to $\mathrm{H}_{2} \mathrm{SO}_{4}$ ), reaching $30.5 \%\left(1149 \mathrm{mg} \mathrm{kg}^{-1}\right)$. Copper extraction in inorganic leaching conditions was maximally $33.5 \%\left(1259 \mathrm{mg} \mathrm{kg}^{-1}\right)$ using $\mathrm{HNO}_{3}$ as an extracting agent. A high $\mathrm{Cu}$ leachability using $\mathrm{HNO}_{3}$ has already been demonstrated [57]. Extraction achieved in organic solutions was lower (up to $17.2 \% \mathrm{Cu}$ ) compared to leaching reached using inorganic leaching agents (Figure 3). For instance, maximal extraction achieved in the case of citric acid was $17.2 \%$ of $\mathrm{Cu}\left(646 \mathrm{mg} \mathrm{kg}^{-1}\right)$

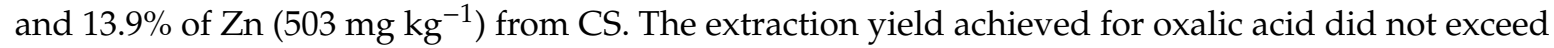
$4.4 \%\left(15.3 \mathrm{~g} \mathrm{~kg}^{-1} \mathrm{Fe}\right)$. The better removal potential of citric acid over oxalic acid has also already been demonstrated $[54,58,59]$. Generally, the extracting agents used revealed the following CS extraction efficiency in decreasing order: $\mathrm{HCl}>\mathrm{HNO}_{3}>\mathrm{H}_{2} \mathrm{SO}_{4}>$ citric $>$ oxalic acid (Figure 3). The reason for such behavior of slags in the presence of these extractants is that $\mathrm{HCl}$ is the strongest acid among the acids studied. A similarly high efficiency of $\mathrm{HCl}$ has already been noted during red mud extraction [60].

\subsection{Silica Gel Formation}

The reason for the relatively low $\mathrm{Cu}$ extraction rates with $\mathrm{H}_{2} \mathrm{SO}_{4}$ can be the potential formation of silica gel in a highly acidic leaching system (Equation (1)). The generation of such gel can entrap metals, including copper $[21,35,61]$. In detail, the leaching medium $\left(\mathrm{H}_{2} \mathrm{SO}_{4}\right)$ was enriched in sulfates. Under such conditions, Si dominates in the form of monomeric $\mathrm{Si}(\mathrm{OH})_{4}$ and once the supersaturation phase is reached, this species polymerizes to a colloidal species, forming a gel [61-63]. Apart from affecting the metal content in the leachate, silica gel also makes the leachate filtration process difficult, as was observed in our case. A similar observation applies to the study of Davris et al. (2017), who reported difficulty in the vacuum pressure filtration process in the presence of silica gel [64]:

$$
2 \mathrm{MeO} \cdot \mathrm{SiO}_{2}+\mathrm{H}_{2} \mathrm{SO}_{4} \rightarrow 2 \mathrm{MeSO}_{4}+\mathrm{H}_{4} \mathrm{SiO}_{4}(\mathrm{Me}: \mathrm{Fe}, \mathrm{Co}, \mathrm{Zn}, \mathrm{Cu} \text { etc.). }
$$

The occurrence of silica gel in this leaching system is proven by a relatively low $\mathrm{Si}$ concentration in the leachate (maximum of 33.6\%) with a simultaneously high concentration of Fe (up to $52.5 \%$; Figure 2). Silicon and iron are incorporated in two primary phases, fayalite and glass [65], thus it would be expected that these two elements are leached at similar rates. The occurrence of an Si-rich surface layer composed of amorphous silica on a fayalite surface has already been reported [66]. However, incomplete Fe solubilization (maximally 68.6\%) from solid to liquid may either suggest that the leaching reaction was not completed during the $48 \mathrm{~h}$ or was due to the formation of precipitates, such as schwertmannite and jarosite, known to form in sulfate-rich solutions [11,67].

Furthermore, an increase of $\mathrm{H}_{2} \mathrm{SO}_{4}$ molarity had an adverse effect on the $\mathrm{Cu}$ extraction efficiency. This serves as an additional argument for the involvement of silica gel as a mechanism inhibiting the presence of dissolved $\mathrm{Cu}$ in the leachate. A similar observation was made by Basir and Rabah (1999), who demonstrated higher $\mathrm{Zn}$ leachability than $\mathrm{Cu}$ from slags [34]. Likewise, Altundogan et al. (2004) observed an over three times lower $\mathrm{Cu}$ extraction rate than $\mathrm{Zn}$ when $1 \mathrm{M} \mathrm{H}_{2} \mathrm{SO}_{4}$ was employed as an extractant [38]. Despite the similarities of our results with the previous study, we find that the most plausible reason for a low content of $\mathrm{Cu}$ in the $\mathrm{H}_{2} \mathrm{SO}_{4}$ leachate is $\mathrm{Cu}$ entrapment in silica gel as explained above. In order to reach a higher extraction rate in the future, the reactor can either be supplemented with $\mathrm{K}_{2} \mathrm{Cr}_{2} \mathrm{O}_{7}$ [38] or alternatively, $\mathrm{H}_{2} \mathrm{O}_{2}$ can be added in order to prevent silica gel formation [21]. Additionally, the supplementation of the leaching reactor with $\mathrm{H}_{2} \mathrm{O}_{2}$ could avoid the 
formation of metal complexes and therefore maintain a high metal content in the dissolved form of the solution [68].

\subsection{Bioleaching Efficiency}

Bioleaching is a cutting-edge technology for metal extraction being studied by numerous research groups dealing with biohydrometallurgy $[11,13,15,69]$. It is known that the chemical process is generally unsurpassed for its shorter duration as compared to a biological process; however, the latter has a "green" connotation, which is seen as highly desirable given current trends in waste management [10]. Both types of slags were subjected to abiotic leaching with a sterile medium (control) and biotic extraction with $A$. thiooxidans. The work of these bacteria in a bioleaching system relies on the production of sulfuric acid as the result of elemental sulfur metabolic oxidation (Equation (2)). The elemental sulfur source in biotic incubations was provided by its initial supplementation to the growth medium. In addition, sulfur originating from sulfidic phases can also be a source (Equation (3)) (for an extended description of sulfur oxidation, see [70,71]). However, based on literature data, negative growth of Acidithiobacillus thiooxidans on sulfide minerals has been demonstrated [70] and the need for sulfur supplementation in the bioleaching system has been highlighted [72]. For example, Kaksonen et al. (2016) pointed out that an increase of bioleaching efficiency by $20 \%$ could be observed in biotic incubations when elemental sulfur was supplemented [72]:

$$
\begin{aligned}
& \mathrm{S}+3 / 2 \mathrm{O}_{2}+\mathrm{H}_{2} \mathrm{O} \rightarrow \mathrm{H}_{2} \mathrm{SO}_{4} \rightarrow \mathrm{SO}_{4}{ }^{2-}+2 \mathrm{H}^{+}, \\
& \mathrm{MeS}_{2}+7 / 2 \mathrm{O}_{2}+\mathrm{H}_{2} \mathrm{O} \rightarrow \mathrm{Me}^{+}+\mathrm{SO}_{4}{ }^{2-}+2 \mathrm{H}^{+} .
\end{aligned}
$$

The leaching trends were alike in the case of both slag types (Figure 6). Dissolution of the slags is governed by: (i) Solution chemistry, mainly the type of extracting agent and its $\mathrm{pH}$; (ii) the phase composition of the slag, because individual phases may dissolve at different rates; and (iii) the type of microorganism acting in the bioleaching system [10]. The kinetics of $\mathrm{Si}, \mathrm{Fe}$, and $\mathrm{Zn}$ (relative \%) dissolution from both studied slags was nearly the same. However, concerning the different chemical composition of these materials, the values $\left(\mathrm{mg} \mathrm{kg}^{-1}\right)$ of the elements in the leachates were different (Figure 6). This trend indicates that at extremely low $\mathrm{pH}$ levels $(<1)$, dissolution of both slags is governed by $\mathrm{pH}$ rather than by the phase composition of the slag itself and bulk slag is dissolved, with a slight preference for $\mathrm{Cu}$ bearing phases of AS. Furthermore, the most significant increase of leaching rates occurred between 4 and 7 days of treatment. It has to be emphasized that these experiments run in parallel and therefore one can assume that at this stage of the experiment the biological activity of A. thiooxidans was alike in both the CS- and AS-containing reactors, implying that: (i) Until the seventh day of the experiment, bacteria remained in an exponential phase; [73] and (ii) bacterial performance was not affected by the metal content in the pregnant leachate [74].

\subsubsection{Crystalline Slag}

As shown in Figure 6, for all the elements studied, higher extraction rates were achieved under biotic conditions as compared to the respective abiotic control. This is undoubtedly related to a lower $\mathrm{pH}$ value in biotic incubation as compared to abiotic conditions (Table 2). The reduction of $\mathrm{pH}$ was due to sulfur oxidation by bacteria $A$. thiooxidans. In addition, dissolution features observed on CS originating from abiotic treatment (Figure $7 \mathrm{~A}, \mathrm{~B}$ ) were less pronounced as compared to features on CS treated with bacteria (Figure 7C-F). As can be seen in Figure 7A,B, fayalite and glass remained not dissolved, whereas Figure 7C-F demonstrate complete fayalite dissolution. Glass and sulfides remained dissolved to a lower degree as compared to fayalite crystals, however, dissolution features on these grains were clearly more pronounced as compared to grains resulting from abiotic leaching.

As the result of the 21-day extractions, the leaching yield was improved by a factor of 43 (CS treated at 5\% PD) and 31 (AS treated at 1\% PD) under biotic conditions (GMB) as compared to abiotic conditions (GM). Generally, biotic treatment of CS resulted in a notably high $\mathrm{Cu}$ and $\mathrm{Zn}$ extraction 
yield when 1\% PD was used. Given such conditions, as much as $52.7 \%$ of $\mathrm{Cu}\left(1981 \mathrm{mg} \mathrm{kg}^{-1}\right)$ and $68.4 \%$ of $\mathrm{Zn}$ (2482) were extracted. Incomplete $\mathrm{Zn}$ extraction refers to the stability of hercynite (Zn-bearing phase, Figure 7) that was surely responsible for the maintenance of this element in the solid phase. The incomplete dissolution of $\mathrm{Cu}$ also indicates that $\mathrm{Cu}$-bearing sulfides (the primary $\mathrm{Cu}$ carriers) were not completely dissolved. Likewise, the extraction of Fe from CS reached $90.6 \%\left(312 \mathrm{mg} \mathrm{kg}^{-1}\right)$. According to scanning electron microscope observations, an exposure of CS to biotic conditions revealed more notable dissolution features (Figure 7C-F) as compared to signs observed on CS exposed to abiotic conditions (Figure 7A,B). Particularly, fayalite was significantly deteriorated (Figure 7C-F), while the glass matrix, despite being altered, still remained distinguishable (Figure 7). A greater degree of fayalite dissolution in bioleaching systems than glass has already been reported [75]. Copper release from CS was related with sulfide (mainly bornite) dissolution as proven by SEM observations (Figure 7D,F). The dissolution of such a mineral phase under exposure to the work of acidophilic bacteria has already been demonstrated [76].
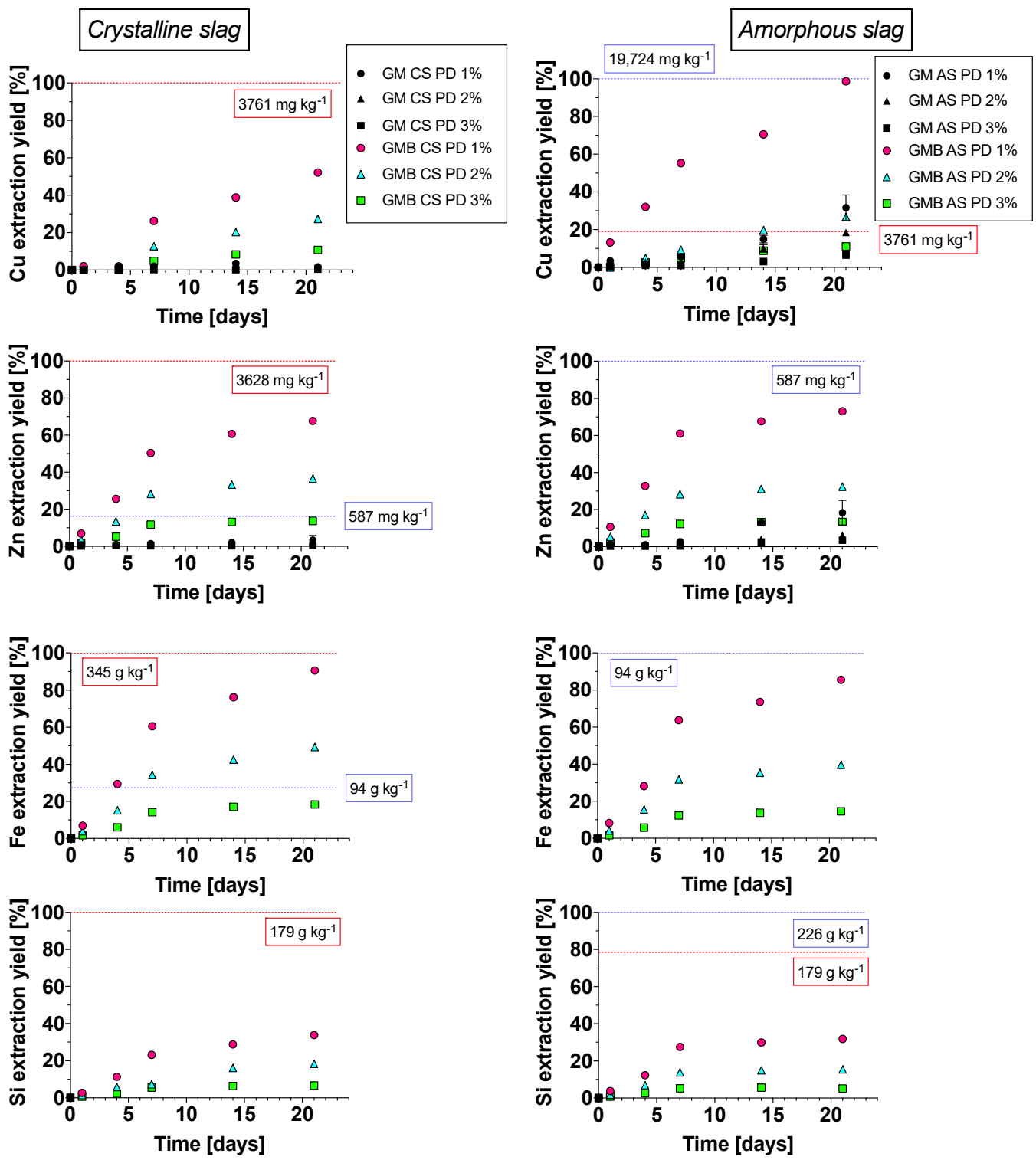

Figure 6. (Bio)extraction of metals from crystalline and amorphous slags treated with growth medium and growth medium with bacteria Acidithiobacillus thioxidans. Values indicated in: (i) red-colored line and rectangle present bulk metal content in CS, (ii) blue-colored line and rectangle indicate bulk metal content in AS. 

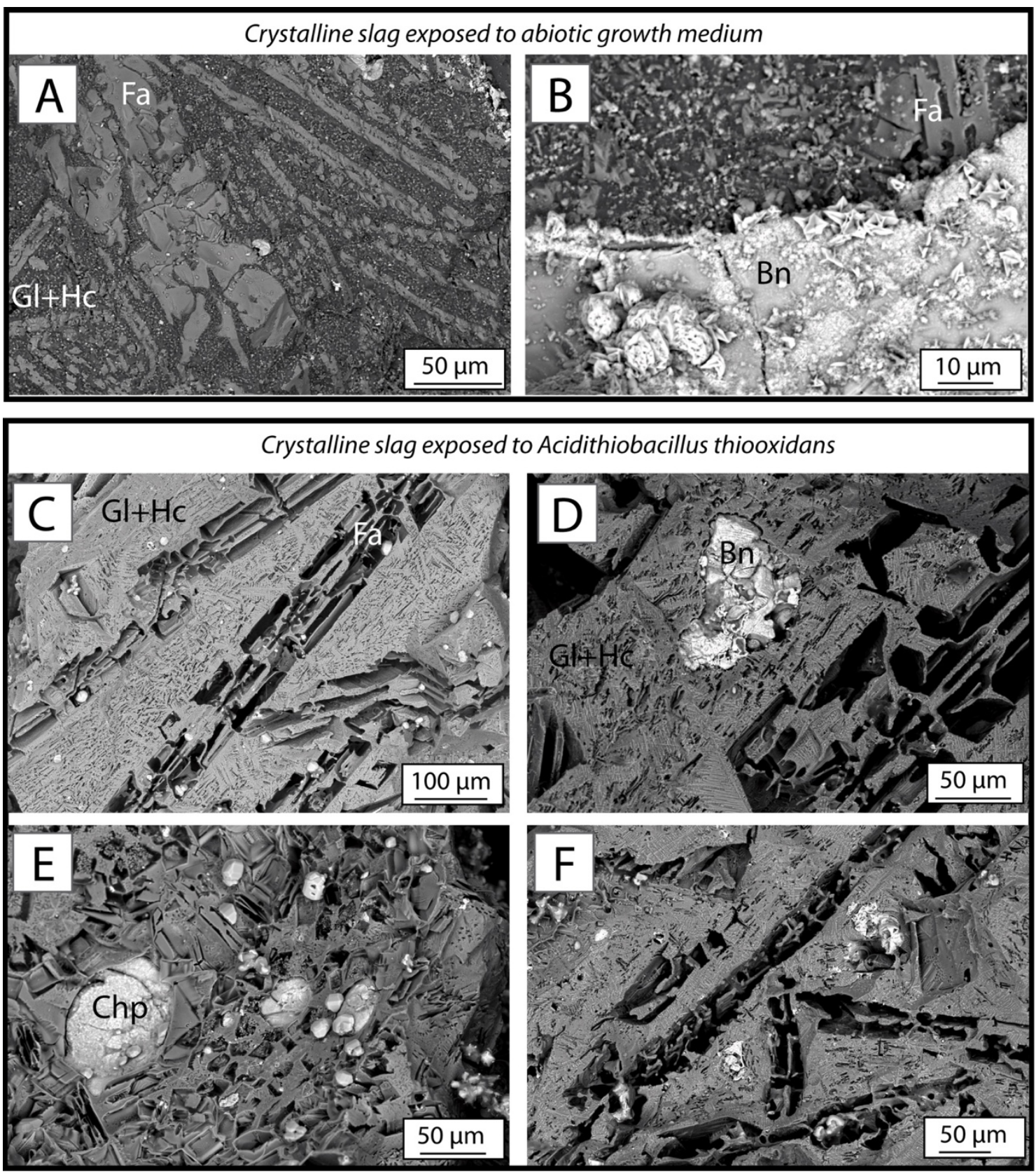

Figure 7. Scanning electron microscope images of CS leached during 21 days in abiotic growth medium and biotic solution with $A$. thiooxidans. Abbreviations: Fa: fayalite, Gl: glass, Hc: hercynite, Bn: bornite, Chp: chalcopyrite. (A,B): Crystalline slag exposed to abiotic growth medium; (C-F): Crystalline slag exposed to Acidithiobacillus thiooxidans.

\subsubsection{Amorphous Slag}

Similarly, AS treated with growth medium remained slightly dissolved (Figure 8A,B), whereas more significant changes were observed after treatment with biotic solution (Figure $8 \mathrm{C}-\mathrm{F}$ ). In the case of AS, dissolution appeared to be even more significant than with CS, because the AS was not only dissolved but appeared to be a residue with a contrasting composition and structure to that observed in the original sample. AS residue was characterized by the presence of gypsum and amorphous silica, both significantly depleted in metals. 

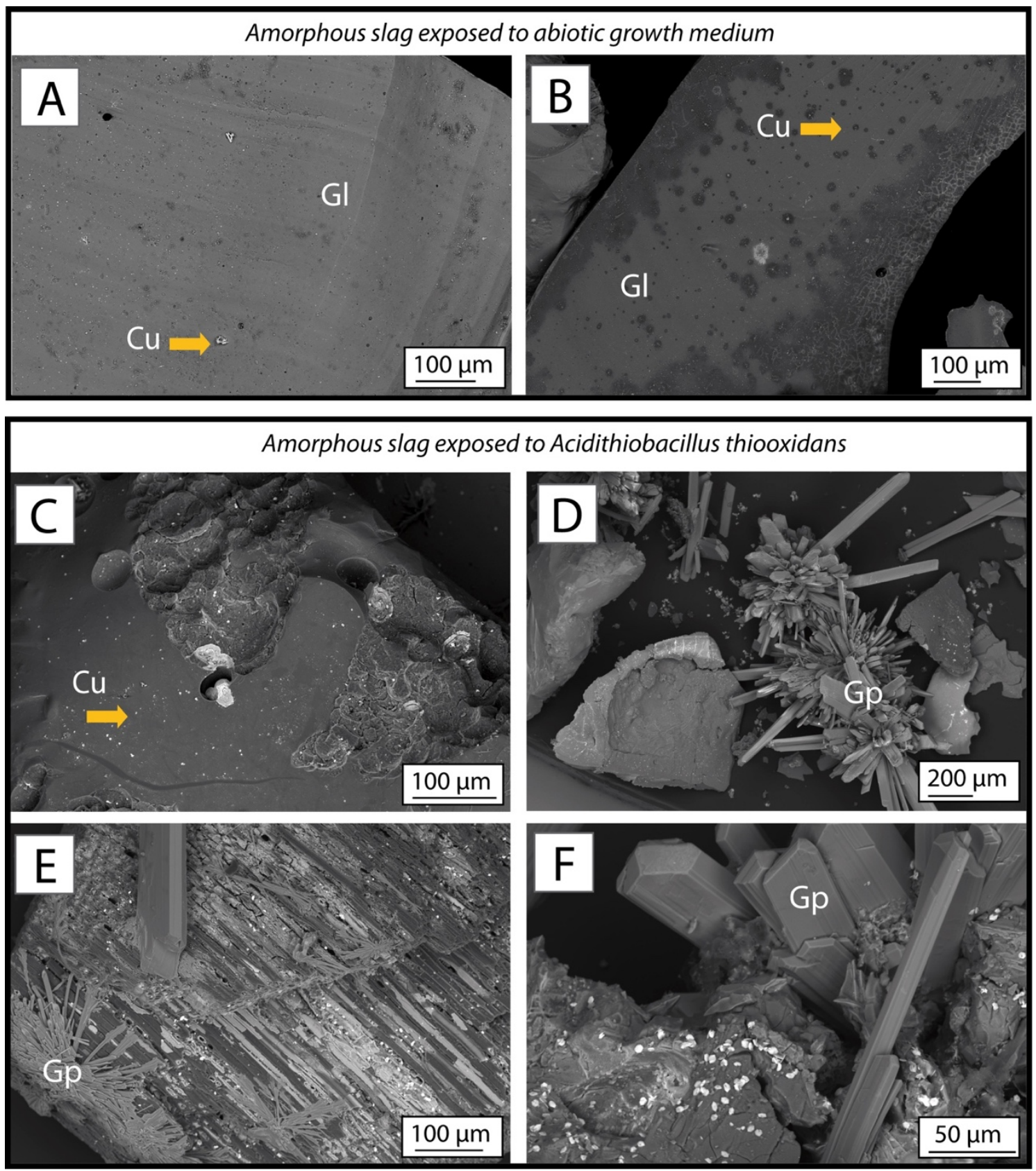

Figure 8. Scanning electron microscope images of AS leached during 21 days in abiotic growth medium and biotic solution with $A$. thiooxidans. Abbreviations: Gl: glass, Cu: metallic copper, Gp: gypsum. (A,B): Amorphous slag exposed to abiotic growth medium; (C-F): Amorphous slag exposed to Acidithiobacillus thiooxidans.

An application of 1\% PD during biotic extraction of AS resulted in a clearly higher efficiency as compared to efficiencies achieved for the $2 \%$ and $5 \%$ treatments. Amorphous slag was highly susceptible to bioleaching, being able to release $98.7 \%$ of $\mathrm{Cu}\left(19,461 \mathrm{mg} \mathrm{kg}^{-1}\right)$ and $73.0 \%$ of $\mathrm{Zn}$ (428 $\mathrm{mg} \mathrm{kg}^{-1}$ ) during the 21-day treatments. For instance, Kaksonen et al. (2016) accomplished extractions of $73 \%$ to $83 \%$ of $\mathrm{Cu}$ and $23 \%$ to $27 \%$ of $\mathrm{Zn}$ during $\mathrm{Cu}$-slag bioleaching with mixed cultures during 47-day treatments at 10\% PD [72]. Thus, it can be assumed that in our case, an application of mixed microbial consortia in the future could be a way to improve extraction yield, especially if Fe-bearing phases are targeted for dissolution. The application of a higher pulp density for bioleaching does not appear to be optimal, since even the use of $5 \%$ PD enabled the extraction of only $10.9 \%(\mathrm{Cu})$ 
and $13.8 \%(\mathrm{Zn})$ in the case of CS and 10\% $(\mathrm{Cu})$ and $13.4 \%(\mathrm{Zn})$ in the case of AS. According to SEM observations, the dissolution of AS under biotic conditions resulted in the generation of gypsum-rich residue (Figure $8 \mathrm{C}-\mathrm{F}$ ) importantly depleted in metals, whereas the dissolution of AS under abiotic conditions resulted in less pronounced dissolution and material remained dissolved but not as much changed due to the biotic conditions in which it took place (Figure 8A,B).

\subsubsection{Comparison of Slag Behavior}

A comparison made between CS and AS shows that when a single metal is targeted for recovery, a suitable material can be chosen. Specifically, as shown in Figure 6, when Cu extraction is targeted, AS appears to be more suitable, because in order to extract $2257 \mathrm{mg} \mathrm{kg}^{-1}$ (the value achieved during CS treatment at $1 \%$ PD over 21 days), only $24 \mathrm{~h}$ of biotic treatment of $\mathrm{AS}$ is required in the same operating conditions. Conversely, CS appears to be more efficient for $\mathrm{Zn}$ and Fe recovery. For example, a 4-day biotic extraction of CS provides higher Zn and Fe leaching yields as compared to a 21-day treatment of AS in the same operating conditions of $1 \%$ PD (Figure 6).

It is important to highlight that in spite of the high metal extraction rate that occurred in biotic incubations, the metals did not pose a notable toxicity threat to the bacteria. Based on the activity test performed after bioleaching, it was found that the bacteria remained active in all biotic incubations. In contrast, no bacterial activity occurred in the test tubes, with abiotic leachate additionally proving that the control conditions remained sterile during the run of the experiment.

Furthermore, it is evident that biotic extraction is longer (Figure 6) as compared to 48-h long, $1 \mathrm{M}$, and normality equivalent acids (chemical) extractions (Figures 3 and 5). However, the advantage of a biotic process is a lower consumption rate of chemicals as only a mineral salt medium is required for the maintenance of microbial growth [77].

\subsection{Phase Dissolution in Bioleaching System}

Calculating the molar ratios of the most easily released element versus other elements specific for individual slag phases is a useful geochemical tool for tracking a phase's dissolution fingerprint [43]. In the case of this study, iron was found to be highly leachable, thus Fe was used as a reference element (Figure 9). Furthermore, $\mathrm{Mg}$ was used to distinguish fayalite dissolution, whereas $\mathrm{Ca}, \mathrm{Al}$, and $\mathrm{K}$ were used to indicate glass dissolution. The molar ratios calculated for $\mathrm{Cu}$ and $\mathrm{Zn}$ aimed to decipher the biodissolution sequence of $\mathrm{Cu}$ - and $\mathrm{Zn}$-bearing phases. Fe/Si molar ratios calculated for slags exposed to bacteria demonstrated that Fe is clearly more leachable from crystalline slag, as $\mathrm{Fe} / \mathrm{Si}$ ratios were far from the theoretical ratios calculated for congruent slag dissolution (Figure 9). In contrast, $\mathrm{Fe} / \mathrm{Si}$ experimental ratios achieved for AS were close to the theoretical ratio, indicating that there was no preference for bioleaching between these two elements. What this implies is that fayalite is more susceptible to dissolution than the glass of crystalline slag. A greater dissolution of crystalline phases as compared to glass under extremely low $\mathrm{pH}$ conditions has also been demonstrated by other authors [78,79]. Furthermore, $\mathrm{Mg}$ being incorporated in the fayalite structure has shown a slight preference towards release at the initial stages $(24 \mathrm{~h})$ of the biotic experiment. It is important to note that leaching of $\mathrm{Fe}$ and $\mathrm{Mg}$ was preferential with respect to $\mathrm{Si}$ in a bioleaching system. Such behavior of fayalite has already been reported [66,80]. As the experiment progressed, Fe/Mg ratios were close to those calculated for congruent dissolution. An additional argument for fayalite dissolution is the trend observed for Zn occurring in fayalite as an impurity. There was a slight preference for Fe release compared to $\mathrm{Zn}$, likely due to the fact that some $\mathrm{Zn}$ is also incorporated in hercynite and glass. The elements $\mathrm{Al}, \mathrm{Ca}$, and $\mathrm{K}$ are contained in a higher quantity in glass; therefore, these are good indicators for fingerprinting this phase's biodissolution. Al and Ca were bioleached with a clear preference of Fe, whereas this preference was less pronounced in the case of K. The preferential release of network-modifying elements (alkali and alkaline-earth metals) from glass surfaces usually occurs due to metal/proton exchange reactions [81], while preference for Fe release in the present study is due to: (i) Higher fayalite dissolution than glass in the case of CS, and (ii) slag conversion to a newly 
formed Ca-rich residue in the case of AS. It is noteworthy that there was a clear preference for $\mathrm{Cu}$ release as compared to $\mathrm{Fe}$, implying that $\mathrm{Cu}$-bearing sulfides are also highly susceptible to leaching as has already been demonstrated [14,78]. However, a higher leachability of $\mathrm{Cu}$ from AS (up to 98.7\%) than CS (up to $52.1 \%$ ) suggests that metallic $\mathrm{Cu}$ is more susceptible to dissolution than $\mathrm{Cu}$-sulfides, which is in accordance with other findings [75].
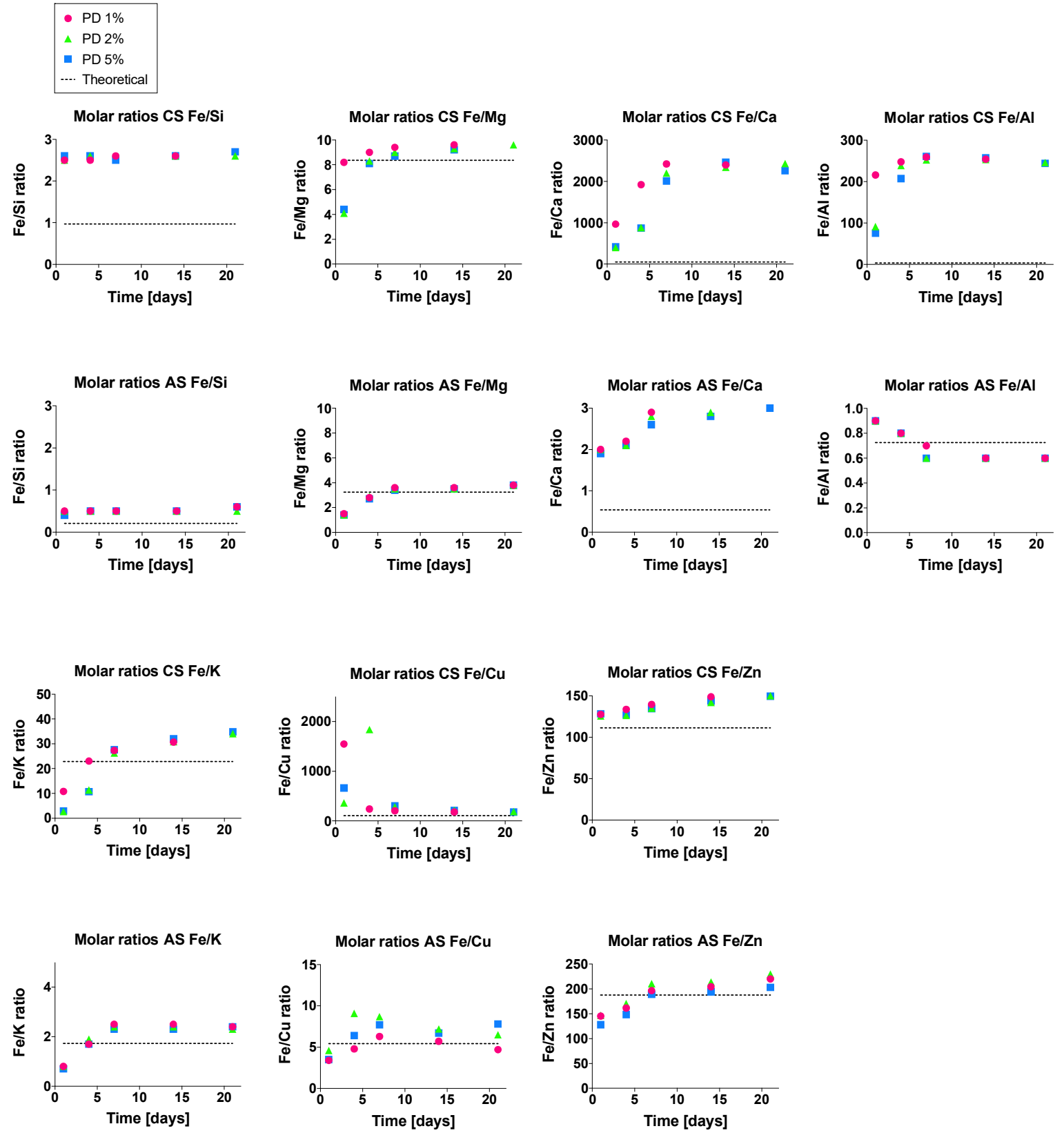

Figure 9. Molar ratios of metal versus Fe in biotic system with slags at various pulp densities.

In the case of amorphous slag, most elements were bioleached in a rather congruent manner, because the ratios achieved experimentally and those calculated for theoretical dissolution were close to overlapping. However, there was a clear preference for Fe release with respect to Ca from this slag and maximal release of Ca was assessed at 14.2\% (AS treated at 1\% PD for 21 days). Solution chemistry, which indicated such a low content of Ca with a simultaneously high content of other elements in the solution, made it necessary to elucidate a mechanism responsible for low Ca content in the solution. As demonstrated by SEM observations, the main phase identified in the leach residue was gypsum 
$\left(\mathrm{CaSO}_{4} \cdot 2 \mathrm{H}_{2} \mathrm{O}\right)$, therefore explaining the Ca presence in the solid. The conversion of amorphous slag to gypsum-rich residue has already been demonstrated [14]. There is no clear preference for any phase to dissolve preferentially when amorphous slag is present in the bioleaching system. In addition, the high release of Ca led to the formation of gypsum in the biotic system, which is congruent with previous findings on other amorphous copper slags [14]. The generation of gypsum as the result of this process potentially allows for the further use of this residue; for example, gypsum is known to reduce exposure of plants to saline stress in soil [82].

It has been shown that in the case of amorphous slag, a 7-day bioleaching treatment seems to be optimal to achieve a satisfactory yield of metals. The use of a $1 \%$ pulp density was found to leach especially well when the experiment progressed onward from the 7-day mark. Similar observations can be made when the behavior of crystalline slag is considered. For pulp densities of $2 \%$ and $5 \%$, the optimal leaching yield was obtained after 7 days, whereas the use of a $1 \%$ pulp density enabled the bioleaching reaction to continue as shown in Figure 6.

\subsection{Economic Potential for Treatment of Historical Slags}

The economic driver is undoubtedly an advantage for specific process developments on a larger scale [83]. Without doubt, when compared to traditional hydrometallurgical processes, the leaching yields obtained in the treatment of historical slags have to be markedly high in order to ensure process profitability. This is mainly connected to the need for slag to be collected from its disposal area and subsequently transferred to a treatment plant; both management activities are inherently associated with extra expenses. However, the additional environmental benefit that could be achieved by removing these wastes from soils is that any future metallic pollution potentially rendered by these slags [50] will then be eliminated, the additional economic value of which is difficult to quantify.

The economic estimation addressed in this study is a theoretical calculation used to present potential differences between the specific treatments (Table 3). It has been made based on average metal values specified on the market in 2019. A complete estimation concerning each element studied is included in Table 1. Depending on the treatment implemented and level of extraction achieved, it has been demonstrated that a gain of up to $\$ 35$ (CS) and $\$ 127$ (AS) (per ton) can be made when treating the slags with $\mathrm{HCl}$ for 48 hours. Biological treatment, despite its longer duration, can bring a slightly higher profit of $\$ 47$ (CS) and $\$ 135$ (AS) per ton of slag treated. However, it is important to point out that in the present study, only selected elements were considered, while profit could presumably be increased when other critical metals are also included. As demonstrated recently, up to an additional $\$ 512$ of profit can be made during biological treatment of one ton of $\mathrm{Cu}$ slags if critical and rare earth elements are taken into consideration too [44].

The commercial applications of bioleaching remain in their infancy at present and are the subject of lukewarm opinions from representatives of the industrial sector. Thus, the data contained here aims to show the preliminary results on extraction efficiency and to convince skeptics about the suitability of slag for metal extraction and potential recovery to be developed in the future management of these wastes. Thus, all leaching studies presented in the literature can be considered as a step from the experimental laboratory stage towards commercial exploitation. Currently, it is known that the primary advantage of chemical treatment is its shorter duration as compared to biotic treatment, as the latter usually requires some time for a bacterial culture to develop and act. On the other hand, chemical treatment consumes extracting agents, which increases the processing expenses incurred and generates chemical wastes that are not environmentally inert. A key advantage of bioleaching is its lack of toxic, highly concentrated acids (e.g., $\mathrm{HCl}$ ) in the procedure. However, it has to be noted that the bioleaching process does require careful consideration of a larger number of variables in order to optimize the process (Table 4). 
Table 3. Estimated economic potential of chemical and biological treatment of slags.

\begin{tabular}{|c|c|c|c|c|c|c|c|c|c|c|c|}
\hline \multirow{4}{*}{$\begin{array}{l}\text { Solution Used as } \\
\text { Extracting Agent }\end{array}$} & \multirow{4}{*}{$\begin{array}{l}\text { Treatment with the Best } \\
\text { Operating Parameters }\end{array}$} & \multicolumn{5}{|c|}{ Crystalline Slag } & \multicolumn{5}{|c|}{ Amorphous Slag } \\
\hline & & Fe & $\mathrm{Cu}$ & Zn & $\mathrm{Pb}$ & & $\mathrm{Fe}$ & $\mathrm{Cu}$ & $\mathrm{Zn}$ & $\mathrm{Pb}$ & $\mathrm{Fe}$ \\
\hline & & 0.09 & 6.5 & 2.8 & 2.1 & Sum & 0.09 & 6.5 & 2.8 & 2.1 & 0.09 \\
\hline & & $\$ \mathrm{~kg}^{-1}$ & $\$ \mathrm{~kg}^{-1}$ & $\$ \mathrm{~kg}^{-1}$ & $\$ \mathrm{~kg}^{-1}$ & & $\$ \mathbf{k g}^{-1}$ & $\$ \mathbf{k g}^{-1}$ & $\$ \mathbf{k g}^{-1}$ & $\$ \mathbf{k g}^{-1}$ & $\$ \mathbf{k g}^{-1}$ \\
\hline & & \multicolumn{10}{|c|}{ Economic Profit Dollars [\$] Per Ton of Slag Treated } \\
\hline Hydrochloric acid & PD: $1 \%, \mathrm{~T}: 48 \mathrm{~h}$ & 20.23 & 7.47 & 7.33 & 0.07 & 35.10 & 6.88 & 118.48 & 1.33 & 0.10 & 126.80 \\
\hline Sulfuric acid & PD: $1 \%, T: 48 \mathrm{~h}$ & 15.49 & 0.35 & 6.09 & 0.03 & 21.95 & 4.42 & 81.19 & 0.88 & 0.02 & 86.51 \\
\hline Nitric acid & PD: $1 \%, T: 48 \mathrm{~h}$ & 16.28 & 8.19 & 5.62 & 0.07 & 30.16 & 5.51 & 101.68 & 1.36 & 0.10 & 108.66 \\
\hline Citric acid & PD: 1\%, T: $48 \mathrm{~h}$ & 2.76 & 4.20 & 1.41 & 0.05 & 8.42 & 7.04 & 109.51 & 1.39 & 0.11 & 118.05 \\
\hline Oxalic acid & PD: $1 \%, \mathrm{~T}: 48 \mathrm{~h}$ & 0.51 & 0.36 & 0.01 & 0.02 & 0.89 & 6.12 & 16.75 & 0.64 & 0.00 & 23.52 \\
\hline Growth medium (sterile) & PD: $1 \%, \mathrm{~T}: 21$ days & 0.00 & 0.42 & 0.35 & 0.00 & 0.77 & 0.00 & 40.58 & 0.30 & 0.00 & 40.89 \\
\hline Growth medium + bacteria & PD: $1 \%, \mathrm{~T}: 21$ days & 27.00 & 12.88 & 6.95 & 0.00 & 46.84 & 6.89 & 126.57 & 1.20 & 0.01 & 134.67 \\
\hline
\end{tabular}

Abbreviations: PD—pulp density, T—-treatment time. Metal prices taken from https://markets.businessinsider.com/commodities. 
Table 4. Comparison of chemical and biological treatment of metallurgical slags.

\begin{tabular}{ccc}
\hline Evaluated Parameter & Chemical Treatment & Biological Treatment \\
\hline $\begin{array}{c}\text { Chemicals consumption during extraction } \\
\text { Processing time } \\
\text { Metal yield }\end{array}$ & $\begin{array}{l}\text { high } \\
\text { short }\end{array}$ & low \\
Environmental impact & high & comparable \\
\end{tabular}

\section{Conclusions}

Metallurgical slags are susceptible to dissolution in inorganic and organic solutions; therefore, these wastes should be considered as prospective candidates for metal extraction and recovery processes rather than simply being disposed of and forgotten. Suitable and efficient treatment depends on the metal(s) targeted and conditions set. Given the right circumstances, amorphous slag was found to be highly susceptible to dissolution. In addition, as a result of the bio-assisted extraction of AS, metal-depleted residue can be generated in the form of gypsum and silica residue, rendering it suitable for even further applications. Crystalline slag subjected to bioleaching resulted in more pronounced fayalite biodissolution as compared to glass, showing it to be a particularly promising candidate for the Fe-recovery process. Chemical treatment is unrivaled in the brevity of its duration as compared to a biological process. Theoretical calculations made based on leachate compositions revealed that the chemical treatment of slags can bring as many as $\$ 35$ and $\$ 127$ of profit (per ton of slag material) in the case of crystalline and amorphous slag, respectively. Additionally, as a result of biologically assisted treatment, a gain of $\$ 47$ and $\$ 135$ can also be made for each ton of CS and AS, respectively.

Author Contributions: Conceptualization, A.P.; Funding acquisition, A.P.; Investigation, A.P.; Methodology, A.P. and J.K.; Visualization, A.P.; Writing—original draft, A.P.; Writing—review and editing, J.K.

Funding: This work was financially supported by the National Science Centre (NCN) in Poland in the frame of the FUGA 5 program under grant agreement UMO-2016/20/S/ST10/00545. Part of this research (mineralogical analyses) has also been supported by statutory funding 0420/2677/18 (Ministry of Science and Education).

Acknowledgments: The authors wish to thank the three anonymous reviewers for their valuable comments which helped us to improve the quality and clarity of the initial version of this manuscript. The authors also thank D. Mitchell for his proofreading services for the final version of this article.

Conflicts of Interest: The authors declare no conflict of interest.

\section{References}

1. Piatak, N.M.; Parsons, M.B.; Seal, R.R. Characteristics and environmental aspects of slag: A review. Appl. Geochem. 2015, 57, 236-266. [CrossRef]

2. Gorai, B.; Jana, R.K. Characteristics and utilisation of copper slag-A review. Resour. Conserv. Recycl. 2003, 39, 299-313. [CrossRef]

3. Ettler, V. Soil contamination near non-ferrous metal smelters: A review. Appl. Geochem. 2015, 64, 56-74. [CrossRef]

4. Kasemodel, M.C.; Papa, T.B.R.; Sígolo, J.B.; Rodrigues, V.G.S. Assessment of the mobility, bioaccessibility, and ecological risk of $\mathrm{Pb}$ and $\mathrm{Zn}$ on a dirt road located in a former mining area-Ribeira Valley-Brazil. Environ. Monit. Assess. 2019, 191, 101. [CrossRef] [PubMed]

5. Forghani, G.; Kelm, U.; Mazinani, V. Spatial distribution and chemical partitioning of potentially toxic elements in soils around Khatoon-Abad Cu Smelter, SE Iran. J. Geochem. Explor. 2019, 196, 66-80. [CrossRef]

6. Moura, W.A.; Gonçalves, J.P.; Lima, M.B.L. Copper slag waste as a supplementary cementing material to concrete. J. Mater. Sci. 2007, 42, 2226-2230. [CrossRef]

7. Shi, C.; Meyer, C.; Behnood, A. Utilization of copper slag in cement and concrete. Resour. Conserv. Recycl. 2008, 52, 1115-1120. [CrossRef]

8. Schmukat, A.; Duester, L.; Ecker, D.; Schmid, H.; Heil, C.; Heininger, P.; Ternes, T.A. Leaching of metal(loid)s from a construction material: Influence of the particle size, specific surface area and ionic strength. J. Hazard. Mater. 2012, 227, 257-264. [CrossRef] [PubMed] 
9. Schmukat, A.; Duester, L.; Ecker, D.; Heininger, P.; Ternes, T.A. Determination of the long-term release of metal(loid)s from construction materials using DGTs. J. Hazard. Mater. 2013, 260, 725-732. [CrossRef] [PubMed]

10. Potysz, A.; van Hullebusch, E.D.; Kierczak, J. Perspectives regarding the use of metallurgical slags as secondary metal resources-A review of bioleaching approaches. J. Environ. Manag. 2018, 219, 138-152. [CrossRef] [PubMed]

11. Kaksonen, A.H.; Särkijärvi, S.; Peuraniemi, E.; Junnikkala, S.; Puhakka, J.A.; Tuovinen, O.H. Metal biorecovery in acid solutions from a copper smelter slag. Hydrometallurgy 2017, 168, 135-140. [CrossRef]

12. Kaksonen, A.H.; Lavonen, L.; Kuusenaho, M.; Kolli, A.; Närhi, H.; Vestola, E.; Puhakka, J.A.; Tuovinen, O.H. Bioleaching and recovery of metals from final slag waste of the copper smelting industry. Miner. Eng. 2011, 24, 1113-1121. [CrossRef]

13. Panda, S.; Mishra, S.; Rao, D.S.; Pradhan, N.; Mohapatra, U.; Angadi, S.; Mishra, B.K. Extraction of copper from copper slag: Mineralogical insights, physical beneficiation and bioleaching studies. Korean J. Chem. Eng. 2015, 32, 667-676. [CrossRef]

14. Potysz, A.; Lens, P.N.L.; van de Vossenberg, J.; Rene, E.R.; Grybos, M.; Guibaud, G.; Kierczak, J.; van Hullebusch, E.D. Comparison of $\mathrm{Cu}, \mathrm{Zn}$ and Fe bioleaching from $\mathrm{Cu}$-metallurgical slags in the presence of Pseudomonas fluorescens and Acidithiobacillus thiooxidans. Appl. Geochem. 2016, 68, 39-52. [CrossRef]

15. Pollmann, K.; Kutschke, S.; Matys, S.; Raff, J.; Hlawacek, G.; Lederer, F.L. Bio-recycling of metals: Recycling of technical products using biological applications. Biotechnol. Adv. 2018, 36, 1048-1062. [CrossRef] [PubMed]

16. Hennebel, T.; Boon, N.; Maes, S.; Lenz, M. Biotechnologies for critical raw material recovery from primary and secondary sources: R\&D priorities and future perspectives. New Biotechnol. 2015, 32, 121-127.

17. Prior, T.; Giurco, D.; Mudd, G.; Mason, L.; Behrisch, J. Resource depletion, peak minerals and the implications for sustainable resource management. Glob. Environ. Chang. 2012, 22, 577-587. [CrossRef]

18. Radetzki, M. Seven thousand years in the service of humanity-the history of copper, the red metal. Resour. Policy 2009, 34, 176-184. [CrossRef]

19. Themelis, N.J. Pyrometallurgy near the end of the 20th century. JOM 1994, 46, 51-57. [CrossRef]

20. Potysz, A.; van Hullebusch, E.D.; Kierczak, J.; Grybos, M.; Lens, P.N.L.; Guibaud, G. Copper metallurgical slags-current knowledge and fate: A review. Crit. Rev. Environ. Sci. Technol. 2015, 45, 2424-2488. [CrossRef]

21. Banza, A.N.; Gock, E.; Kongolo, K. Base metals recovery from copper smelter slag by oxidising leaching and solvent extraction. Hydrometallurgy 2002, 67, 63-69. [CrossRef]

22. Carranza, F.; Romero, R.; Mazuelos, A.; Iglesias, N.; Forcat, O. Biorecovery of copper from converter slags: Slags characterization and exploratory ferric leaching tests. Hydrometallurgy 2009, 97, 39-45. [CrossRef]

23. Tong, D.; Yunhan, L. Processing of copper converter slag for metal reclamation. Part I: Extraction and recovery of copper and cobalt. Waste Manag. Res. 2007, 25, 440-448. [CrossRef] [PubMed]

24. Giller, K.E.; Witter, E.; Mcgrath, S.P. Toxicity of heavy metals to microorganisms and microbial processes in agricultural soils: A review. Soil Biol. Biochem. 1998, 30, 1389-1414. [CrossRef]

25. Sahni, A.; Kumar, A.; Kumar, S. Chemo-biohydrometallurgy-A hybrid technology to recover metals from obsolete mobile SIM cards. Environ. Nanotechnol. Monit. Manag. 2016, 6, 130-133. [CrossRef]

26. Sukla, L.B.; Kar, R.N.; Panchanadikar, V. Leaching of copper converter slag with Aspergillus niger culture filtrate. Biometals 1992, 5, 169-172. [CrossRef]

27. Gadd, G.M. Metals, minerals and microbes: Geomicrobiology and bioremediation. Microbiology 2010, 156, 609-643. [CrossRef] [PubMed]

28. Anand, S.; Sarveswara Rao, K.; Jena, P.K. Pressure leaching of copper converter slag using dilute sulphuric acid for the extraction of cobalt, nickel and copper values. Hydrometallurgy 1983, 10, 305-312. [CrossRef]

29. Altundoğan, H.S.; Tümen, F. Metal recovery from copper converter slag by roasting with ferric sulphate. Hydrometallurgy 1997, 44, 261-267. [CrossRef]

30. Beşe, A.V.; Ata, O.N.; Çelik, C.; Çolak, S. Determination of the optimum conditions of dissolution of copper in converter slag with chlorine gas in aqueous media. Chem. Eng. Process. 2003, 42, 291-298. [CrossRef]

31. Sukla, L.B.; Panda, S.C.; Jena, P.K. Recovery of cobalt, nickel and copper from converter slag through roasting with ammonium sulphate and sulphuric acid. Hydrometallurgy 1986, 16, 153-165. [CrossRef]

32. Nadirov, R.K.; Syzdykova, L.I.; Zhussupova, A.K.; Usserbaev, M.T. Recovery of value metals from copper smelter slag by ammonium chloride treatment. Int. J. Miner. Process. 2013, 124, 145-149. [CrossRef] 
33. Herreros, O.; Quiroz, R.; Manzano, E.; Bou, C.; Viñals, J. Copper extraction from reverberatory and flash furnace slags by chlorine leaching. Hydrometallurgy 1998, 49, 87-101. [CrossRef]

34. Basir, S.M.; Rabah, M.A. Hydrometallurgical recovery of metal values from brass melting slag. Hydrometallurgy 1999, 53, 31-44. [CrossRef]

35. Yang, Z.; Rui-Lin, M.; Wang-Dong, N.; Hui, W. Selective leaching of base metals from copper smelter slag. Hydrometallurgy 2010, 103, 25-29. [CrossRef]

36. Ahmed, I.M.; Nayl, A.A.; Daoud, J.A. Leaching and recovery of zinc and copper from brass slag by sulfuric acid. J. Saudi Chem. Soc. 2016, 20, 280-285. [CrossRef]

37. Arslan, C.; Arslan, F. Recovery of copper, cobalt, and zinc from copper smelter and converter slags. Hydrometallurgy 2002, 67, 1-7. [CrossRef]

38. Altundogan, H.S.; Boyrazli, M.; Tumen, F. A study on the sulphuric acid leaching of copper converter slag in the presence of dichromate. Miner. Eng. 2004, 17, 465-467. [CrossRef]

39. Baghalha, M.; Papangelakis, V.G.; Curlook, W. Factors affecting the leachability of Ni/Co/Cu slags at high temperature. Hydrometallurgy 2007, 85, 42-52. [CrossRef]

40. Potysz, A.; Grybos, M.; Kierczak, J.; Guibaud, G.; Lens, P.N.L.; van Hullebusch, E.D. Bacterially-mediated weathering of crystalline and amorphous Cu-slags. Appl. Geochem. 2015, 64, 92-106. [CrossRef]

41. Kierczak, J.; Potysz, A.; Pietranik, A.; Tyszka, R.; Modelska, M.; Néel, C.; Ettler, V.; Mihaljevič, M. Environmental impact of the historical Cu smelting in the Rudawy Janowickie Mountains (south-western Poland). J. Geochem. Explor. 2013, 124, 183-194. [CrossRef]

42. Potysz, A.; Kierczak, J.; Fuchs, Y.; Grybos, M.; Guibaud, G.; Lens, P.N.L.; van Hullebusch, E.D. Characterization and $\mathrm{pH}$-dependent leaching behaviour of historical and modern copper slags. J. Geochem. Explor. 2016, 160, 1-15. [CrossRef]

43. Potysz, A.; Kierczak, J.; Pietranik, A.; Kądziołka, K. Mineralogical, geochemical, and leaching study of historical Cu-slags issued from processing of the Zechstein formation (Old Copper Basin, southwestern Poland). Appl. Geochemistry 2018, 98, 22-35. [CrossRef]

44. Mikoda, B.; Potysz, A.; Kmiecik, E. Bacterial leaching of critical metal values from Polish copper metallurgical slags using Acidithiobacillus thiooxidans. J. Environ. Manag. 2019, 236, 436-445. [CrossRef] [PubMed]

45. Stuurman, S.; Ndlovu, S.; Sibanda, V. Comparing the extent of the dissolution of copper-cobalt ores from the DRC region. J. S. Afr. Inst. Min. Metall. 2014, 114, 347-349.

46. Crundwell, F.K. The mechanism of dissolution of minerals in acidic and alkaline solutions: Part III. Application to oxide, hydroxide and sulfide minerals. Hydrometallurgy 2014, 149, 71-81. [CrossRef]

47. Watling, H.R. The bioleaching of sulphide minerals with emphasis on copper sulphides-A review. Hydrometallurgy 2006, 84, 81-108. [CrossRef]

48. Beşe, A.V. Effect of ultrasound on the dissolution of copper from copper converter slag by acid leaching. Ultrason. Sonochem. 2007, 14, 790-796. [CrossRef]

49. Dopson, M.; Halinen, A.K.; Rahunen, N.; Boström, D.; Sundkvist, J.E.; Riekkola-Vanhanen, M.; Kaksonen, A.H.; Puhakka, J.A. Silicate mineral dissolution during heap bioleaching. Biotechnol. Bioeng. 2008, 96, 288-293. [CrossRef]

50. Potysz, A.; Kierczak, J.; Grybos, M.; Pędziwiatr, A.; van Hullebusch, E.D. Weathering of historical copper slags in dynamic experimental system with rhizosphere-like organic acids. J. Environ. Manag. 2018, 222, 325-337. [CrossRef]

51. Urosevic, D.M.; Dimitrijevic, M.D.; Jankovic, Z.D.; Antic, D.V. Recovery of copper from copper slag and copper slag flotation tailings by oxidative leaching. Physicochem. Probl. Miner. Process. 2015, 51, 73-82.

52. Lewis, A.E. Review of metal sulphide precipitation. Hydrometallurgy 2010, 104, 222-234. [CrossRef]

53. Sethurajan, M.; Huguenot, D.; Lens, P.N.L.; Horn, H.A.; Figueiredo, L.H.A.; Van Hullebusch, E.D. Leaching and selective copper recovery from acidic leachates of Três Marias zinc plant (MG, Brazil) metallurgical purification residues. J. Environ. Manag. 2016, 177, 26-35. [CrossRef] [PubMed]

54. Mulligan, C.N.; Kamali, M.; Gibbs, B.F. Bioleaching of heavy metals from a low-grade mining ore using Aspergillus niger. J. Hazard. Mater. 2004, 110, 77-84. [CrossRef] [PubMed]

55. Niu, Z.; Zou, Y.; Xin, B.; Chen, S.; Liu, C.; Li, Y. Process controls for improving bioleaching performance of both $\mathrm{Li}$ and $\mathrm{Co}$ from spent lithium ion batteries at high pulp density and its thermodynamics and kinetics exploration. Chemosphere 2014, 109, 92-98. [CrossRef] [PubMed] 
56. Kuo, Y.M.; Wang, J.W.; Wang, C.T.; Tsai, C.H. Effect of water quenching and $\mathrm{SiO}_{2}$ addition during vitrification of fly ash. Part 1: On the crystalline characteristics of slags. J. Hazard. Mater. 2008, 152, 994-1001. [CrossRef]

57. Mohanty, U.; Rintala, L.; Halli, P.; Taskinen, P.; Lundström, M. Hydrometallurgical approach for leaching of metals from copper rich side stream originating from base metal production. Metals 2018, 8, 40. [CrossRef]

58. Khodadoust, A.P.; Reddy, K.R.; Maturi, K. Effect of different extraction agents on metal and organic contaminant removal from a field soil. J. Hazard. Mater. 2005, 117, 15-24. [CrossRef]

59. Astuti, W.; Hirajima, T.; Sasaki, K.; Okibe, N. Comparison of effectiveness of citric acid and other acids in leaching of low-grade Indonesian saprolitic ores. Miner. Eng. 2016, 85, 1-16. [CrossRef]

60. Ujaczki, É.; Zimmermann, Y.S.; Gasser, C.A.; Molnár, M.; Feigl, V.; Lenz, M. Red mud as secondary source for critical raw materials-Extraction study. J. Chem. Technol. Biotechnol. 2017, 92, 2835-2844. [CrossRef]

61. Najafi, M.; Rostamian, R.; Rafati, A.A. Chemically modified silica gel with thiol group as an adsorbent for retention of some toxic soft metal ions from water and industrial effluent. Chem. Eng. J. 2011, 168, 426-432. [CrossRef]

62. Terry, B. The acid decomposition of silicate minerals part I. Reactivities and modes of dissolution of silicates. Hydrometallurgy 1983, 10, 135-150. [CrossRef]

63. Shahid, M.; Dumat, C.; Pourrut, B.; Silvestre, J.; Laplanche, C.; Pinelli, E. Influence of EDTA and citric acid on lead-induced oxidative stress to Vicia faba roots. J. Soils Sediments 2014, 14, 835-843. [CrossRef]

64. Davris, P.; Stopic, S.; Balomenos, E.; Panias, D.; Paspaliaris, I.; Friedrich, B. Leaching of rare earth elements from eudialyte concentrate by suppressing silica gel formation. Miner. Eng. 2017, 108, 115-122. [CrossRef]

65. Kierczak, J.; Pietranik, A. Mineralogy and composition of historical Cu slags from the Rudawy Janowickie mountains, Southwestern Poland. Can. Miner. 2011, 49, 1281-1296. [CrossRef]

66. Kobayashi, M.; Sawada, A.; Tani, Y.; Soma, M.; Tanaka, A.; Honma, T.; Seyama, H.; Theng, B.K.G. Acid dissolution of olivines, feldspars and dunite. Water. Air. Soil Pollut. 2001, 130, 757-762. [CrossRef]

67. Wang, H.; Bigham, J.M.; Tuovinen, O.H. Formation of schwertmannite and its transformation to jarosite in the presence of acidophilic iron-oxidizing microorganisms. Mater. Sci. Eng. C 2006, 26, 588-592. [CrossRef]

68. De Michelis, I.; Ferella, F.; Karakaya, E.; Beolchini, F.; Vegliò, F. Recovery of zinc and manganese from alkaline and zinc-carbon spent batteries. J. Power Sour. 2007, 172, 975-983. [CrossRef]

69. Schippers, A. Bioleaching of copper slag material. Solid State Phenom. 2017, 262, 61-64. [CrossRef]

70. Wang, R.; Lin, J.Q.; Liu, X.M.; Pang, X.; Zhang, C.J.; Yang, C.L.; Gao, X.Y.; Lin, C.M.; Li, Y.Q.; Li, Y.; et al. Sulfur oxidation in the acidophilic autotrophic Acidithiobacillus spp. Front. Microbiol. 2019, 9, 1-20. [CrossRef]

71. Suzuki, I.; Silver, M. The initial product and properties of the sulfur-oxidizing enzyme of thiobacilli. $B B A$ Enzymol. Biol. Oxid. 1966, 122, 22-33. [CrossRef]

72. Kaksonen, A.H.; Särkijärvi, S.; Puhakka, J.A.; Peuraniemi, E.; Junnikkala, S.; Tuovinen, O.H. Chemical and bacterial leaching of metals from a smelter slag in acid solutions. Hydrometallurgy 2016, 159, 46-53. [CrossRef]

73. Yin, H.; Zhang, X.; Li, X.; He, Z.; Liang, Y.; Guo, X.; Hu, Q.; Xiao, Y.; Cong, J.; Ma, L.; et al. Whole-genome sequencing reveals novel insights into sulfur oxidation in the extremophile Acidithiobacillus thiooxidans. BMC Microbiol. 2014, 179, 1-14. [CrossRef] [PubMed]

74. Barreira, R.P.R.; Villar, L.D.; Garcia, O. Tolerance to copper and zinc of Acidithiobacillus thiooxidans isolated from sewage sludge. World J. Microbiol. Biotechnol. 2005, 21, 89-91. [CrossRef]

75. Kaksonen, A.H.; Särkijärvi, S.; Puhakka, J.A.; Peuraniemi, E.; Junnikkala, S.; Tuovinen, O.H. Solid phase changes in chemically and biologically leached copper smelter slag. Miner. Eng. 2017, 106, 97-101. [CrossRef]

76. Bevilaqua, D.; Garcia, O.; Tuovinen, O.H. Oxidative dissolution of bornite by Acidithiobacillus ferrooxidans. Process Biochem. 2010, 45, 101-106. [CrossRef]

77. Pathak, A.; Dastidar, M.G.; Sreekrishnan, T.R. Bioleaching of heavy metals from sewage sludge: A review. J. Environ. Manag. 2009, 90, 2343-2353. [CrossRef] [PubMed]

78. Ettler, V.; Mihaljevic, M.; Touray, J.C.; Piantone, P. Leaching of polished sections: An integrated approach for studying the liberation of heavy metals from lead-zinc metallurgical slags. Bull. Soc. Geol. Fr. 2002, 173, 161-169. [CrossRef]

79. Vítková, M.; Ettler, V.; Johan, Z.; Kř́bek, B.; Šebek, O.; Mihaljevič, M. Primary and secondary phases in copper-cobalt smelting slags from the Copperbelt Province, Zambia. Miner. Mag. 2010, 74, 581-600. [CrossRef]

80. Seyama, H.; Soma, M.; Tanaka, A. Surface characterization of acid-leached olivines by X-ray photoelectron spectroscopy. Chem. Geol. 1996, 129, 209-216. [CrossRef] 
81. Thomassin, J.H.; Touray, J.C. Etude des premiers stades de l'interaction eau-verre basaltique: Données de la spectrométrie de photoélectrons (XPS) et de la microscopie électronique à balayage. Bull. Mineral. 2019, 102, 594-599. [CrossRef]

82. Makoi, J.H.J.R.; Verplancke, H. Effect of gypsum placement on the physical chemical properties of a saline sandy loam soil. Aust. J. Crop Sci. 2010, 4, 556-563.

83. Pathak, A.; Morrison, L.; Healy, M.G. Catalytic potential of selected metal ions for bioleaching, and potential techno-economic and environmental issues: A critical review. Bioresour. Technol. 2017, 229, 211-221. [CrossRef] [PubMed]

(C) 2019 by the authors. Licensee MDPI, Basel, Switzerland. This article is an open access article distributed under the terms and conditions of the Creative Commons Attribution (CC BY) license (http://creativecommons.org/licenses/by/4.0/). 